\title{
Origin and Accumulation of Trace Elements in Sediments of the Northwestern Mediterranean Margin
}

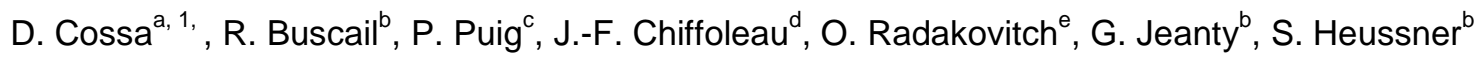

\author{
a Ifremer, Centre de Méditerranée, BP 330, F-83507 La Seyne-sur-Mer, France \\ b Cnrs, CEntre de Formation et de Recherche sur les Environnements Méditerranéens, UMR 5110, F-66860, \\ Perpignan, France \\ ${ }^{\mathrm{C}}$ Marine Sciences Institute, CSIC, E-08003 Barcelona, Spain \\ d Ifremer, Centre Atlantique, BP 21105, F-44311 Nantes Cedex 03, France \\ e Cerege, Université Aix-Marseille, Cnrs Umr 7330, F-13545 Aix-en-Provence Cedex 4, France
}

${ }^{1}$ Present address : ISTerre, Université J. Fourier, BP 53, F-38041 Grenoble, France. Tel.: + 33476635928 ; email address : dcossa@ifremer.fr

\begin{abstract}
:
Continental margins receive natural and anthropogenic trace elements (TEs) from direct atmospheric deposition of aerosols onto the sea surface and from advection of riverine suspended particles and/or resuspended sediments from the continental shelf/slope. When the margin is incised by submarine canyons, as for example in the Northwestern Mediterranean Sea, most of these particles are preferentially transferred via these topographic features towards their final repositories in the abyssal plain. The Gulf of Lions (GoL) shelf receives the largest particulate riverine input to the Western Mediterranean, with its associated chemical contaminants originating from the industrialized and urbanized Rhone Valley. Sediments samples (grabs, cores and moored traps) collected in the Cap de Creus $(\mathrm{CdC})$ Canyon and its adjacent areas at the Southwestern exit of the GoL were analyzed to explore the origin, dispersion, transfer and accumulation of a suite of TEs $(\mathrm{Ag}, \mathrm{Cd}, \mathrm{Co}, \mathrm{Cr}, \mathrm{Cu}, \mathrm{Ni}, \mathrm{Pb}$, $\mathrm{Zn}$ and V) from the GoL shelf to the adjacent continental rise. Distributions of $\mathrm{Cu}, \mathrm{Cr}, \mathrm{Ni}, \mathrm{Pb}, \mathrm{Zn}$ and $\mathrm{V}$ in the surface sediments of the shelf confirm their terrigenous origin in association with clay minerals, whereas $\mathrm{Ag}$ and $\mathrm{Cd}$ are more associated with organic matter (OM). All these TEs are anthropogenically enriched in the Rhone prodelta sediments. Anthropogenic influence remains clearly discernible in the GoL shelf surface sediments for $\mathrm{Ag}, \mathrm{Pb}$ and $\mathrm{Zn}$. Hydrodynamical resuspension and sorting of shelf sediments occur at the head of the CdC Canyon during dense shelf-water cascading events. During these events, the material collected in moored sediment traps contains a higher coarse carbonate fraction slightly impoverished in TEs compared to the clays of the nepheloid layer and the organically-rich particles deposited before and at the end of the cascading period. Upper and middle canyon sediments are characterized by high sedimentation rates $\left(\sim 0.2 \mathrm{~cm} \mathrm{yr}^{-1}\right)$ of fine clay material. Conversely, sediments from the lower continental slope and rise exhibit low sedimentation rates $\left(\sim 0.06 \mathrm{~cm} \mathrm{yr}^{-1}\right)$ and receive carbonaceous planktonic detritus from the water column. At the lower continental slope, coarse material includes foraminifers and pteropods, whereas at the continental rise finer planktonic-derived material is more abundant. Both in the $\mathrm{CdC}$ Canyon and in its adjacent lower continental slope/rise sediments, $\mathrm{Co}, \mathrm{Cu}, \mathrm{Cr}$, Ni and $\mathrm{V}$ are associated with clay, whereas $\mathrm{Ag}$, $\mathrm{Cu}$ and $\mathrm{Pb}$ are preferentially associated with $\mathrm{OM}$. Cadmium, $\mathrm{Cr}$, and $\mathrm{Zn}$ are also associated with $\mathrm{OM}$ in canyon sediments. Carbonaceous plankton appears to be especially efficient for scavenging $\mathrm{Ag}$,
\end{abstract}


whereas, $\mathrm{Cr}, \mathrm{V}, \mathrm{Zn}$ and $\mathrm{Pb}$ are diluted by biogenic carbonates. An authigenic $\mathrm{Mn}$ fraction is enriched with $\mathrm{Co}$ and $\mathrm{Ni}$. Lead and $\mathrm{Zn}$ concentration levels and vertical profile patterns, along with $\mathrm{Pb}$ stable isotopic ratios, indicate that significant parts of $\mathrm{Pb}$ and $\mathrm{Zn}$ are of anthropogenic origin. A sediment chronology based on ${ }^{210} \mathrm{~Pb}$ dating reveals that $\mathrm{Pb}$ anthropization, mainly from gasoline additives, culminated between 1960 and 1980, being the current concentrations $>40 \%$ lower than 30 years ago. A similar distribution is observed for $\mathrm{Zn}$, which originates mainly from combustion processes; but the reduction of $\mathrm{Zn}$ contamination amounts to only $20 \%$ during the same period. The largest anthropogenic $\mathrm{Pb}$ accumulation occurs in the middle part of $\mathrm{CdC}$ Canyon, with an inventory of $200 \mathrm{\mu g} \mathrm{cm}^{-2}$. At the most distal part of the continental rise anthropogenic $\mathrm{Pb}$ accumulation within the first $\sim 10 \mathrm{~cm}$ below the surface sediment is estimated around $10 \mathrm{\mu g} \mathrm{cm}^{-2}$, which is similar to the direct atmospheric deposition estimate.

\section{Highlights}

We study trace element (TE) in NW-Mediterranean margin sediments TE are hosted by different sediment fractions (clay, organic and authigenic matter) - Cascading sorts the material transported to canyons and affects its TE composition - Anthropogenic TE accumulated in canyon sediments, with maximum in 1960-70 AD $>\mathrm{Ag}$ is strongly associated with carbonaceous planktonic remains

Keywords : Trace-element ; Sediment ; Canyon ; continental margin ; Mediterranean

\section{Introduction}

Open ocean deep ecosystems are generally considered as being less impacted by human activities than coastal areas. Indeed, they mainly receive contaminants from atmospheric deposition, whereas continental margins additionally receive riverine inputs often loaded with chemicals. (e.g., Hickey et al., 1986; Monaco et al., 1999; Puig et al., 2003; Canals et al., 2006; Heussner et al., 2006; de Stigter et al., 2007; Ogston et al., 2008; Puig et al., 2014). Chemical contaminants have been found in sediments within various submarine canyons around the world ocean off California (e.g., Maurer et al., 1996; Puig et al., 1999; Palanques et al., 2008; Richter et al., 2009; Heimbürger et al., 2012; Salvado et al., 2012a and b), suggesting that these morphological features act as natural sediment traps. Nevertheless, the main processes controlling the transfer of these chemicals within submarine canyons and towards deep sediments is still poorly known. 
Sediment dynamics of the Gulf of Lions (GoL) and its canyons, in the Northwestern Mediterranean (NWM), are well documented (see for example the Continental Shelf Research, 28, 2008 special issue). The main inputs of sedimentary material to the GoL shelf are provided by Rhone River floods (discharges $>3000 \mathrm{~m}^{3} \mathrm{~s}^{-1}$ ), which are identifiable in the deposits of its proximal delta (Cathalot et al., 2010; Pastor et al., 2011; Révillon et al., 2011; Fanget et al., 2013). Other riverine sources in the same area are poorly preserved due to wave-induced sediment resuspension especially during storms (Guillen et al., 2006 ; Bourrin et al., 2007 ; Kim et al., 2009) and dense shelf-water cascading events (Durrieu de Madron et al., 2008; Roussiez et al., 2012). These two wind-driven processes limit the longterm sediment deposition on the shelf, and the general westward water mass circulation directs most of the export of suspended sediment towards the southwestern exit of the GoL, (Durrieu de Madron et al., 2008), especially the Cap de Creus (CdC) Canyon (Palanques et al., 2006a; DeGeest et al., 2008). Tesi et al. (2010) estimated that $98 \%$ of the entire terrigenous organic matter (OM) export in the CdC Canyon occurred during dense shelf-water cascading events. Part of the sediments entering the GoL canyons forms temporary deposits in their upper/middle reaches, which act as a trap for particulate OM and associated trace elements (TEs) (Buscail et al., 1997). However, these sediments are periodically resuspended and flushed to deeper canyon reaches, and further down to the abyssal plain (DeGeest et al., 2008; Puig et al., 2008; Palanques et al., 2012; Stabholz et al., 2013). Being the main outlet of sediment temporarily trapped on the GoL shelf, the CdC Canyon represents thus an interesting site for assessing the contamination transfer from the industrialized Rhone Valley to the NWM deep ecosystems.

In order to assess the offshore dispersal of natural and anthropogenic TEs in the NWM margin, we have determined the elemental composition of settling particles and deposited sediments from the Rhone prodelta to the Catalan continental rise following the GoL shelf and the CdC Canyon dispersal pathway. The following specific questions were also addressed in this article: (i) is the canyon a trap or just a channel for the oceanic transfer of particulate TEs? (ii) what is the role of the cascading events in this transfer? (iii) what is the part of the direct atmospheric deposition at open sea in sedimentary TE of the continental rise? (iv) what are the magnitude of anthropogenic fractions of TEs, their sources and the chronology of their inputs, both in the canyon and on the continental slope and rise?

\section{Materiel and methods}




\subsection{Sampling}

Four sediments cores were collected along the $\mathrm{CdC}$ Canyon with the R/V UnIVERSITATIS in October 2005 at stations G, H, I and L (Fig. 1) using a multicore sampler (Multiple corer type) allowing the sampling of the undisturbed benthic interface (Barnett et al., 1984). Cores G (960 m depth, $28 \mathrm{~cm} \mathrm{long)}$ and $\mathrm{H}$ (1473 m depth, $34 \mathrm{~cm}$ long) were located within in the upper and middle part of the canyon (Lastras et al., 2007), whereas cores I (1874 m depth, $20 \mathrm{~cm}$ long) and L (2335 $\mathrm{m}$ depth, $8 \mathrm{~cm} \mathrm{long)}$ were located at the lower continental slope and on the continental rise, respectively. The cores were sliced on board every half centimeter until $2 \mathrm{~cm}$, then every centimeter until $20 \mathrm{~cm}$, and finally every two centimeters. Undisturbed surface sediments $(0-1 \mathrm{~cm})$ were also collected on the GoL shelf, from the Rhône prodelta to the head of the CdC Canyon using a box corer during the R/V ENDEAVOR cruise in April 2004 (Fig. 1). Sediments were quickly frozen $\left(-18^{\circ} \mathrm{C}\right)$ on board after sub-sampling, then freezedried and stored in dark in the laboratory until analysis. Coordinates of the sampling stations are given in table $\mathrm{S} 1$.

Settling particles were collected from October 2004 to May 2005, a period of major cascading and storm events in the GoL (Puig et al., 2008; Tesi et al., 2010), using a sediment trap (PPS3, Technicap) placed at $30 \mathrm{~m}$ above the bottom on a mooring deployed at $500 \mathrm{~m}$ water depth at the $\mathrm{CdC}$ Canyon head $\left(42^{\circ} 22.27^{\prime} \mathrm{N} ; 3^{\circ} 21.69^{\prime} \mathrm{E}\right.$, ST, Fig. 1). Sediment trap cups were filled with buffered formaldehyde; the collected material was stored at $+4^{\circ} \mathrm{C}$ after sieving through a $1 \mathrm{~mm}$ nylon mesh to retain the large swimming organisms that occasionally enter the traps during sampling. It was then precisely divided into sub-samples for subsequent analyses using a WSD-10 McLane wet sample divider. A sub-sample from each trap was inspected under microscope to remove the remaining small swimmers with tweezers and was freeze-dried and stored in dark until analysis.

\subsection{Dating and mixing}

Activities of ${ }^{210} \mathrm{~Pb}$ in sediments were measured according to the method described by Radakovitch and Heussner (1999). Briefly, after complete acid digestion of the sample, its granddaughter ${ }^{210} \mathrm{Po}$ was spontaneously deposited on a silver disc. The disc was then placed between $\mathrm{ZnS}(\mathrm{Ag})$ phosphors and counted on a total alpha counter. As ${ }^{210} \mathrm{Po}$ and ${ }^{210} \mathrm{~Pb}$ are in secular equilibrium within sediments, only one deposition and counting was performed on the sediment samples. Supported

${ }^{210} \mathrm{~Pb}$ was calculated from the mean of constant activities measured at the bottom of each cores, and excess ${ }^{210} \mathrm{~Pb}$ equals total ${ }^{210} \mathrm{~Pb}$ minus supported. Sedimentation rates have been calculated using both constant flux-constant sedimentation (CFCS) and constant initial concentration (CIC) models, based on ${ }^{210} \mathrm{~Pb}$ in excess $\left({ }^{210} \mathrm{~Pb}_{\mathrm{ex}}\right)$ distributions (Appleby \& Oldfield, 1978).

$$
\left[{ }^{210} \mathrm{~Pb}_{\mathrm{xs}}\right]_{\mathrm{z}}=\left[{ }^{210} \mathrm{~Pb}_{\mathrm{xs}}\right]_{0} \mathrm{e}^{-\lambda(\mathrm{z} / \tau)}
$$

where $\left[{ }^{210} \mathrm{~Pb}_{\mathrm{xs}}\right]_{0, \mathrm{z}}$ are the activities of excess ${ }^{210} \mathrm{~Pb}$ at surface, or the base of the mixed layer, and depth $\mathrm{z}, \lambda$ the decay constant of ${ }^{210} \mathrm{~Pb}\left(0.03114 \mathrm{yr}^{-1}\right)$, and $\tau$ the sedimentation rate. 


\subsection{Analytical techniques}

Total carbon $(\mathrm{Ct})$, organic carbon $\left(\mathrm{C}_{\text {org }}\right)$ and total nitrogen $(\mathrm{Nt})$ contents were analyzed by combustion in an automatic CN-analyzer (LECO 2000), after acidification of the samples with 2M HCl (overnight at $50^{\circ} \mathrm{C}$ ) to remove inorganic carbon prior to the analyses of $\mathrm{C}_{\text {org }}$ (Cauwet et al, 1990). Calcium carbonate content was calculated from mineral carbon $\left(\mathrm{Ct}-\mathrm{C}_{\text {org }}\right)$ using the molecular mass ratio $\left(\mathrm{CaCO}_{3}: \mathrm{C}=\right.$ 100:12). Extensive testing at CEFREM laboratory showed long-term precisions for $\mathrm{C}_{\text {org }}$ and $\mathrm{Nt}$ of about $2 \%$ and for $\mathrm{Ct}$ of $0.3 \%$.

Elemental composition (Ca, Al, Fe, Li, V, Cr, Mn, Ni, Cu, Zn, Ag, Cd, Co and Pb with its stable isotopes) were performed after total dissolution of sediment with a mixture of $\mathrm{HCl}, \mathrm{HNO}_{3}$, and $\mathrm{HF}$ in hermetically sealed Teflon bombs according to the protocol described by Loring and Rantala (1990) and modified by Chiffoleau et al. (2004). All reagents used were SupraPur®, obtained from Merck. The concentrations were determined using an inductive coupled plasma mass spectrometer (ICP-MS, Thermo Electron Corporation, Element X Series®). Iron and Al concentrations were determined by atomic absorption spectrophotometry (AAS, Varian, SpectrAA 600®). The determinations were validated using certified reference materials (CRMs): MESS-3 and BCSS-1, from the National Research Council of Canada. A blank sample and CRM were included with each batch of 15 samples in the total digestion procedure and then analyzed with ICP-MS and AAS. The blank values were always below the detection limits. Values obtained for elemental analysis were always within the range of certified values.

\subsection{Statistical Analysis and Normalization}

Principle Components Analysis (PCA), a multivariate technique, was applied to reduce the number of variables to a smaller number of factors that describe the principal variability or joint behavior of the data set. Geometrically, this new set of variables represents a principal axis rotation of the original coordinate axes of the variables around their mean (Jackson, 2003; Huang et al., 2010). The statistical computations were performed with XLSTAT ${ }^{\circledR}$ software from Addinsoft.

To test if the observed variations in the surface sediments were the result of mineral changes, the TE concentrations were geochemically normalized by the use of a tracer element (Kersten and Smedes, 2002). Lithium was chosen as the granulometric normalizer element to take into account the clay fraction with its high specific surface, which favors metal binding for $\mathrm{Co}, \mathrm{Cr}, \mathrm{Cu}, \mathrm{Ni}, \mathrm{Pb}, \mathrm{V}$ and $\mathrm{Zn}$ (Loring, 1990). Lithium was preferred to Al since its relationship with TEs was statistically stronger 
(Tables S2 and S3). According to Loring (1990) Li is incorporated in fine-grained aluminosilicate metal-bearing minerals, but not in the Al-rich but metal-poor feldspars that occur throughout the grain size spectrum of such sediments. Similar normalization method was already used successfully for Mediterranean sediments (Aloupi and Angelidis, 2001).

\section{Results}

\subsection{Major element composition of surface sediments and trap particles}

Summary statistics for the major element composition of surface sediments from the Rhone prodelta to the NWM continental rise as well as in trapped particles are presented in Table 1. Mean carbonate concentrations were high in surface sediments from the continental rise where they reached values up to 62 and $46 \%$ for core I and L, respectively. High concentrations of $\mathrm{Al}$ and $\mathrm{Li}$ were found in the surface sediments, within the canyon (cores $\mathrm{G}$ and $\mathrm{H}$ ) and lower values corresponded to sediments at the continental rise. A large variability of $\mathrm{Al}, \mathrm{Li}, \mathrm{Fe}$ and carbonate was observed in particles collected in the trap moored at the head of the canyon (ST, Table 1) displaying lower Al, Fe and Li concentrations and higher carbonate contents, during March 2005 (Fig. 2). High $\mathrm{C}_{\mathrm{org}}$ concentrations (> 1\% d.w.) were found in the Rhone prodelta (RD) surface sediments and lower values $(<0.5 \%)$ in the surface sediment of the continental rise. The $\mathrm{C} / \mathrm{N}$ ratios were relatively low $(7.2-7.4)$ within the continental shelf sediments (SH) and at the head of the CdC Canyon (HD and ST). C/N ratios $>10$ in continental rise surface sediments.

\subsection{Major element composition of sediment cores}

Grain size and elemental composition of the sediment cores are given in Table S4 and summary statistics for the major element composition in Table 2. Sand fraction $(>63 \mu \mathrm{m})$ distribution varied between cores, with higher proportions for cores I and L. These cores exhibited increasing proportion of sand from the bottom to the surface of the cores. Visual observations of core I showed a larger abundance of foraminifers at depths between 2 and $8 \mathrm{~cm}$ and pteropods between 9 and $14 \mathrm{~cm}$. Elementary compositions differed between canyon cores ( $\mathrm{G}$ and $\mathrm{H}$ ) and lower continental slope/rise cores (I and L). Mean carbonate concentrations were significantly lower $(\mathrm{p}<0.01$, T-tests) in cores $G$ and $\mathrm{H}(27.3$ and $27.9 \%$ ) than in cores I and L (39.1 and 41.3\%) (Table 2). Carbonate profiles were homogenous in cores $\mathrm{G}$ and $\mathrm{H}$, whereas lower values with increasing depth were observed in cores I and L (Fig. S1a). Aluminum concentrations varied from 6 to $7 \%$ in cores $\mathrm{G}$ and $\mathrm{H}$, and were significantly 
lower ( $\mathrm{p}<0.001$, T-tests) in cores I and L (3.5 - $5.5 \%)$ (Table 2, Fig. S1c). Similar patterns were observed for Li and Fe (Fig. S1d). Vertical profiles of Al and Fe mirrored those of carbonate in the 4 cores. In summary, the fine clay fraction dominated in the canyon sediments, whereas the coarse carbonate fraction dominated in continental rise sediments.

Mean $\mathrm{C}_{\text {org }}$ concentrations in cores $\mathrm{G}$ and $\mathrm{H}$ were higher than those in cores $\mathrm{I}$ and $\mathrm{L}(\mathrm{p}<0.01$, T-tests). The highest $\mathrm{C}_{\text {org }}$ concentrations were found near the sediment surface (Fig. S1b), suggesting an active remineralization within the sedimentary column. The $\mathrm{C}_{\text {org }}$ remained high down to $15 \mathrm{~cm}$ in core $\mathrm{H}$, suggesting a rapid particulate accumulation. Carbon to nitrogen ratios $(\mathrm{C} / \mathrm{N})$ were quite homogenous throughout the sediment column in most cores, except in core L (Fig. S2a), where the low values (4 -7) suggest the presence of preserved planktonic OM.

\subsection{Sedimentation rates in the canyon and on the continental rise/slope}

${ }^{210} \mathrm{~Pb}_{\mathrm{ex}}$ profiles (Fig. S3) show that $\mathrm{ln}^{210} \mathrm{~Pb}_{\mathrm{ex}} v \mathrm{~s}$ depth for core $\mathrm{H}$ can be better defined by assuming different linear relationships and thus change in sedimentation. Sedimentation rates varied depending on

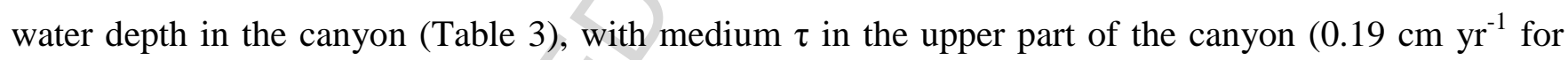
core $\mathrm{G})$, high $\tau$ in the middle of the canyon $\left(0.18-0.52 \mathrm{~cm} \mathrm{yr}^{-1}\right.$ for core $\left.\mathrm{H}\right)$ and low $\tau$ for the lower continental slope/rise $\left(0.02-0.06 \mathrm{~cm} \mathrm{yr}^{-1}\right.$ for cores I and L). The ${ }^{210} \mathrm{~Pb}_{\mathrm{ex}}$ inventories allow once more the differentiation along the slope (Table 3). For the I and L cores, inventory values were in the lower range of those obtained by Miralles et al. (2005) for the open slope of the GoL (0.27-0.57 Bq cm $\left.{ }^{-2}\right)$ and similar to the $0.280 \mathrm{~Bq} \mathrm{~cm}$ obtained by Angelidis et al (2011) for three cores in the Western Mediterranean abyssal plain. For the $\mathrm{G}$ and $\mathrm{H}$ cores, inventory values were 10 times higher, similar to the range of values measured for the GoL canyons (Miralles et al., 2005). Such high values suggest a large sediment focusing within the canyon.

\subsection{Trace element composition in surface sediments and material from traps $(\mathrm{Ag}, \mathrm{Cd}, \mathrm{Co}, \mathrm{Cr}, \mathrm{Mn}$, $\mathrm{Ni}, \mathrm{Pb}, \mathrm{V}, \mathrm{Zn})$}

According to summarized statistics (Table 4), TEs can be sorted out in three groups. First highest Ag, $\mathrm{Cd}, \mathrm{Cu}$, and $\mathrm{Zn}$ mean concentrations were found at Rhone prodelta stations (RD), where they exceed continental crust concentrations. This indicates that the Rhone River is the main anthropogenic source for these TEs. The second group gathers $\mathrm{Cr}, \mathrm{Ni}, \mathrm{Pb}$ and $\mathrm{V}$, which present the highest mean concentrations in the canyon (cores $\mathrm{G}$ and $\mathrm{H}$ ). Concentration values, except for $\mathrm{Pb}$, did not differ significantly $(\mathrm{p}<0.001)$ from crustal background. The third group is composed by $\mathrm{Mn}$ and Co showing 
enriched values compared to continental crust composition. This is the case of surface sediments from the continental rise, the CdC Canyon and the material collected in the trap (Tables 1 and 4). The TE composition of trapped material (ST) displayed large temporal variations. In March 2005, TE concentrations were systematically lower than during the other periods, similarly to $\mathrm{Li}$ and $\mathrm{Al}$ variations (Fig. 2).

\subsection{Trace element composition of the cores ( $\mathrm{Ag}, \mathrm{Cd}, \mathrm{Co}, \mathrm{Cr}, \mathrm{Mn}, \mathrm{Ni}, \mathrm{V}, \mathrm{Zn})$}

Summary statistics are given in Table S5. Concentrations of these TEs in CdC Canyon sediments were in the range of continental crust concentrations (Table 4). The distributions of $\mathrm{V}, \mathrm{Ni}, \mathrm{Cr}, \mathrm{Cd}$, and $\mathrm{Zn}$ were strongly linked to those of $\mathrm{Li}$ and Al, with highly significant correlation coefficients between these five elements ranging from 0.70 to 0.97 ( $\mathrm{p}<0.001$ ) (Table S2). Vanadium, $\mathrm{Cr}, \mathrm{Zn}$ and $\mathrm{Pb}$ displayed Li or Al-like vertical profiles (Figs. 3 and S1c) suggesting their association with clay minerals. In addition, TEs mean concentrations were systematically lower $(\mathrm{p}<0.001$, T-test) in cores I and L than in core G and $\mathrm{H}$ (Table S5), with the notable exception of $\mathrm{Ag}$, which exhibited the largest and lowest concentrations for core I and L respectively (Fig. 3). Manganese distribution in the 4 cores showed background concentrations between 550 and $700 \mu \mathrm{g} \mathrm{g}^{-1}$, and large amplitude maxima at various depths depending on the core (Fig. S2), a characteristic feature of Mn oxihydroxides authigenic formation. The presence of multiple $\mathrm{Mn}$ peaks in cores $\mathrm{G}, \mathrm{H}$ and $\mathrm{L}$ suggests a temporal variation in the oxygen penetration, which could have resulted from pulses in $\mathrm{C}_{\text {org }}$ sedimentation.

\subsection{Lead and its stable isotopes in the cores}

Lead concentrations varied from 16 to $71 \mu \mathrm{g} \mathrm{g}^{-1}$, with the lowest value associated with the deep layer in core I, and the highest at the subsurface layer of core G (Fig. 3). Surface concentrations of cores G and $\mathrm{H}$ were similar $\left(\sim 42 \mu \mathrm{g} \mathrm{g}^{-1}\right)$ with subsurface peaks: a sharp peak at $3.5 \mathrm{~cm}$ in core $\mathrm{G}$ and a bump between $6-13 \mathrm{~cm}$ in core $\mathrm{H}$. Concentrations decreased in the bottom layers of both cores, down to 20 and $37 \mu \mathrm{g} \mathrm{g}^{-1}$ for $\mathrm{G}$ and $\mathrm{H}$, respectively. Along the continental slope/rise (cores $\mathrm{I}$ and $\mathrm{L}$ ), $\mathrm{Pb}$ concentrations decreased from the top $\left(28 \mu \mathrm{g} \mathrm{g}^{-1}\right)$ to the bottom of the core, where the values $<20 \mu \mathrm{g} \mathrm{g}^{-1}$ were very close to crustal concentrations ( $\mathrm{Li}, 2000)$ (Table 4, Fig. 3). The concentration levels and the shapes of $\mathrm{Pb}$ vertical profiles, both suggested the presence of anthropogenic $\mathrm{Pb}$ with maxima along the vertical distributions at $3.5 \mathrm{~cm}$ (core G), $10 \mathrm{~cm}$ (core H), and at the surface for cores I and L. The stable isotopic ratios showed low values $\left(0.475\right.$ and 1.163 for ${ }^{206} \mathrm{~Pb} /{ }^{208} \mathrm{~Pb}$ and ${ }^{206} \mathrm{~Pb} /{ }^{207} \mathrm{~Pb}$ respectively, corresponding to the largest anthropogenic influence) within the $\mathrm{Pb}$ maximum in core $\mathrm{G}$. In the deepest 
layer, isotopic ratios converged to 0.483 and 1.196 for ${ }^{206} \mathrm{~Pb} /{ }^{208} \mathrm{~Pb}$ and ${ }^{206} \mathrm{~Pb} /{ }^{207} \mathrm{~Pb}$ respectively, which are values close to the natural $\mathrm{Pb}$ ratios (Fig. 4, Table 5).

\section{Discussion}

\subsection{Origin of the TEs of shelf surface sediments}

The GoL watershed consists predominantly of sedimentary rocks, including sandstone, limestone, dolomite, marl and shale (Radakovitch et al., 2008). Metamorphic and igneous rocks cover only $15 \%$ of the Rhone watershed but constitute more than $50 \%$ of the catechement basins of the GoL western rivers of the Pyrenees Mountain. However, the influence of these western rivers is very small in the GoL, since $80 \%$ of the riverine particles delivered to this area are delivered by the Rhone River, and only $2 \%$ from the Pyrenean rivers (Gairoard et al., 2012). Révillon et al. (2011) also pointed out, on the basis of geochemical analyses, that GoL sediments mainly originate from the Rhone River.

The significant correlations ( $\mathrm{p}<0.001$, Table $\mathrm{S} 3$ ) between $\mathrm{Li}$ (or $\mathrm{Al}$ ) and $\mathrm{Cr}, \mathrm{Cu}, \mathrm{Ni}, \mathrm{Pb}, \mathrm{V}$, and $\mathrm{Zn}$, suggest a chemical association or a common origin with continental clay for these TEs. The case of $\mathrm{Zn}$ and $\mathrm{Pb}$ is however somehow different since these two TEs have a significant anthropogenic origin. On the one hand, $\mathrm{Zn}$ mean concentration in the prodelta sediments $\left(131 \mu \mathrm{g} \mathrm{g}^{-1}\right.$, Table 4$)$ is almost twice the average value of the upper continental crust composition $\left(71 \mu \mathrm{g} \mathrm{g}^{-1}\right.$, Table 4). On the other hand, low values of the ${ }^{206 / 207} \mathrm{~Pb}$ ratios obtained for surface sediments (1.174-1.190, Table S6), are typical of human impregnated sediments (Komarek et al., 2008). This range is similar to the one published earlier for surface sediment from the same region (1.176-1.188, Roussiez et al., 2005).

These significant relationships allow to use the lithium normalization procedure (see section 2.4.) for the calculation of enrichments factors $\left(\mathrm{EF}=[\mathrm{TE} / \mathrm{Li}]_{\text {sample }} /[\mathrm{TE} / \mathrm{Li}]_{\text {preindustrial background }}\right)$. The preindustrial background ratios were estimated from deep horizons $(4-8 \mathrm{~m})$ of a Rhone prodelta core (core KS-57, see Fanget et al., 2013). The calculated EFs are $\sim 2$ for $\mathrm{Cu}, \mathrm{Pb}$, and $\mathrm{Zn}$ for the prodelta area (Table 6). For material collected elsewhere on the shelf and in trapped material $\mathrm{Pb}$ enrichment factor values remain significantly $>1\left(\mathrm{EF}_{\mathrm{Pb}}: 1.7-2.0, \mathrm{p}<0.01\right.$, T-test $)$, whereas $\mathrm{EF}_{\mathrm{Zn}}$ are only slightly $>1\left(\mathrm{EF}_{\mathrm{Zn}}\right.$ $1.2-1.4, p<0.05, T$-test). The EFs for other TEs do not differ significantly ( $p>0.05$ ) from 1 (Table 6). Our Li-based EF values are similar to the Cs-based EFs previously calculated for $\mathrm{Cu}$ and $\mathrm{Zn}$ for the surface sediment of the entire GoL shelf (Roussiez et al., 2006). 
Concentrations for $\mathrm{Ag}$ and $\mathrm{Cd}$ (Table 4) in surface sediments from the Rhone prodelta area show values three times higher compared to those from other parts of the shelf suggesting, like for $\mathrm{Pb}$ and $\mathrm{Zn}$, a human impregnation of the RD sediments as a result of Rhone River particulate contamination. However, these two covariant TEs are not Li-dependent, but rather correlated with $\mathrm{C}_{\text {org }}(\mathrm{p}<0.01$, Tables S2 and S3). Cadmium contamination in surface sediment of river estuaries of the GoL has already been reported (Roussiez et al., 2006; Radakovitch et al., 2008) and frequently originates from the use of phosphate fertilizers in the river catchments (WHO, 1992). An agricultural origin for $\mathrm{Cd}$ in GoL sediments is supported by the relationship between $\mathrm{P}$ and $\mathrm{Cd}$ previously pointed out by Radakovitch et al. (2008). The Ag contamination shown by our results is the first report for this region. It has been considered as a marker for urban sewage (Sanudo-Wilhelmy and Flegal, 1992; Kim et al., 2010). The use of $\mathrm{Ag}$ has increased in the past 30 years for agricultural and industrial activities (Lanceleur et al., 2011). It is, therefore, not surprising that the Rhone prodelta sediments, which are the first repository site for organic-rich land-born material (Kim et al, 2010b; Bourgeois et al, 2011; Fanget et al., 2013), are affected by $\mathrm{Ag}$ and $\mathrm{Cd}$ enriched discharges along the agriculturally active and urbanized Rhone valley.

\subsection{Origin of the TEs in the trap-material at the head of CdC Canyon}

The 2004-2005 winter was cold enough to promote to the formation of an exceptional dense-water mass on the GoL shelf. Consequently, a significant cascading event occurred at the end of February and during March 2005 over the entire GoL that was particularly intense within the CdC Canyon (Canals et al., 2006; Puig et al., 2008; Tesi et al., 2010). The same authors further noticed that advection within nepheloid layers prevailed during relatively quiescent conditions, while, during the dense water cascading event, the nature of particles exported through the canyon was affected by hydrodynamic sorting. Fine material was transported during the pre- and post-cascading conditions, whereas coarse material prevailed during the cascading event. The variations in elemental composition of particles collected by the traps moored at the head of the canyon (ST, Fig.1), therefore, reflect the changes in resuspended sediment sources. Indeed, from October 2004 to January 2005, and in spring 2005, the carbonate material was significantly $(\mathrm{p}<0.001)$ lower than in March 2005: $25.0 \pm 1.4 \%(\mathrm{n}=16)$ vs $31.7 \pm$ $2.0(\mathrm{n}=7) \%$. Our results show that relatively coarse carbonate sediment is the major component of the mass flux during the cascading event, mainly being composed by broken shell fragments. Such carbonate material is slightly impoverished in TEs compared to the clays transported via nepheloid 
layers (Fig. 2). This TE difference is clearly due to differences in grain size since it disappears when using EFs instead of concentrations (Table 6).

\subsection{Origin and behavior of TEs in sediments of the CdC Canyon and its adjacent continental slope/rise}

\subsubsection{Sediment characteristics}

Supplementary Information (SI 1) details major geochemical characteristics of the 4 sediment cores collected within the CdC Canyon and on the lower continental slope and rise. In summary, canyon cores are characterized by high sedimentation rates $\left(\sim 0.2 \mathrm{~cm} \mathrm{yr}^{-1}\right)$ of fine clay material, especially in the middle of the canyon (core $\mathrm{H}$ ), where sedimentation reaches $0.5 \mathrm{~cm} \mathrm{yr}^{-1}$, and where high ${ }^{210} \mathrm{~Pb}$ inventory confirms large sediment fluxes (Table 3). Canyon sediments receive inputs from the GoL shelf, especially during cascading events (see above). At the lower continental slope (core I), coarse carbonate material, including foraminifers and pteropods, accumulates, whereas, at the continental rise (core L) finer planktonic-derived material is more abundant. These two cores have low sedimentation rates $\left(\sim 0.06 \mathrm{~cm} \mathrm{yr}^{-1}\right)$ and their ${ }^{210} \mathrm{~Pb}$ inventories suggest that they receive most of their material from downward settling from the upper water column, in addition to particles episodically advected from the margin during deep cascading pulses (Tesi et al., 2010; Salat et al., 2010; Puig et al., 2013).

\subsubsection{Hosting phases and diagenetic redistribution of TES}

The PCAs using major and trace element concentrations were performed on our data set, one for the for the $\mathrm{CdC}$ Canyon cores and the other adjacent continental slope/rise cores. Both PCAs reveal that the largest part of the overall variability (F1: 36 and 52\% for the canyon and lower continental slope/rise cores respectively) is given by the association of $\mathrm{Co}, \mathrm{Cr}, \mathrm{Ni}$, and $\mathrm{V}$ (with, in addition, $\mathrm{Cu}$ and $\mathrm{Zn}$ for lower continental slope/rise sediments) with clay markers ( $\mathrm{Li}$ and $\mathrm{Al}$ ). The second major inference from PCAs is the association of $\mathrm{OM}$ markers $\left(\mathrm{C}_{\text {org }}\right.$ and $\left.\mathrm{Nt}\right)$ with $\mathrm{Ag}, \mathrm{Cu}$ and $\mathrm{Pb}$ in both environments, and with, in addition, $\mathrm{Cd}, \mathrm{Cr}$, and $\mathrm{Zn}$ in canyon sediments (F2: 26 and $16 \%$ for the canyon and lower continental slope/rise cores, respectively). The third component (F3) of the PCAs associates Mn and Co (16 and 14\% of the total variability in canyon and lower continental slope/rise cores respectively, Tables S7a and b), suggesting the existence of an authigenic fraction. Thus, based on correlation coefficients between major elements and component-factors of the PCAs (Tables S7a and b), F1 and F2 clearly indicate lithogenic and organic components, respectively, whereas F3 indicates a Mn-enriched fraction, which more than likely consists of authigenic Mn-oxihydroxides (Fig. S2b). 
The TEs-clay association has already been described for surface sediments from the GoL shelf (Roussiez et al., 2005, 2006; Radakovitch et al., 2008) and their continental origin clearly established. The hosting role of $\mathrm{OM}$ for $\mathrm{Cr}, \mathrm{Cu}, \mathrm{Pb}$ and $\mathrm{Zn}$ is also a well documented pattern in modern and ancient marine sediments (e.g., Petersen et al., 1995; Tribovillard et al. 2006; Algeo and Maynard, 2004; Belicka et al., 2009; Böning et al., 2009). Studies addressing Ag biogeochemistry in coastal and marine sediments are scarse, but the Ag interaction with planktonic material and its highly dynamic diagenetic behaviour have been already reported (Crusius and Thomson, 2003; Morford et al., 2008).

The $\mathrm{TE} / \mathrm{Li}$ vs $\mathrm{C}_{\text {org }}$ relationships observed in our cores illustrate the various affinities of TEs for various types of OM (Fig. 5). Steeper slopes indicate higher OM control on TE. Firstly, the OM dependence decreases from $\mathrm{Ag}-\mathrm{Cu}-\mathrm{Co}$ to $\mathrm{Cr}-\mathrm{Ni}-\mathrm{V}$, with $\mathrm{Pb}$ and $\mathrm{Zn}$ having intermediate affinities. Secondly, regression coefficients are higher in sediments from the continental rise (core L) for $\mathrm{Ag}, \mathrm{Cu}$ and $\mathrm{Co}, \mathrm{Cd}, \mathrm{Ni}$, and $\mathrm{V}$. Interestingly, these TEs are classified as biologically dependent in sea water (Nozaki, 2001); in other words, their transfer to sediments is governed by the "biological pump". Thirdly, the "y intercepts" (TE/Li for $\mathrm{OM}=0$ ) for $\mathrm{Ag}, \mathrm{Cd}, \mathrm{Co}, \mathrm{Cr}, \mathrm{Cu}, \mathrm{Ni}$ and $\mathrm{V}$ in canyon cores $(\mathrm{G}$ and $\mathrm{H})$ remain unchanged, suggesting a common source for terrigenous TEs, most probably the Rhone watershed as proposed by Révillon et al. (2011). This interpretation supposes that authigenic fractions are small for these metals, which, as a first approximation, is reasonable for continental margin sediments (van der Weijden et al., 2006). Large calcareous marine plankton, such as foraminifers and pteropods present in core I, appears to be an efficient scavenger for Ag (Fig. 3). This has been already shown for other TEs in the water column mixed layer, allowing rapid Ag transfer down to sediments (e.g., Turekian et al., 1973; Elderfield et al., 1996). In core I, the high affinity of Ag for foraminifers and pteropods is further attested by the significant relationships of $\mathrm{Ag}$ with carbonate $\left(\mathrm{R}^{2}=0.88, \mathrm{p}<0.001\right)$, and N/C $\left(\mathrm{R}^{2}=0.60, \mathrm{p}<0.001\right)$, since carbonate and high $\mathrm{N} / \mathrm{C}$ ratio indicate a calcareous plankton signature. In contrast, $\mathrm{Cr}, \mathrm{V}, \mathrm{Zn}$ and $\mathrm{Pb}$ are diluted by biogenic carbonates (Fig. 3).

Once delivered by settling OM, small fractions of TEs are retained into authigenic sedimentary phases formed during OM mineralization, such as oxihydroxides and sulfides (Gobeil et al., 1987 and 1997; Morford and Emerson, 1999; Sundby et al., 2004; Morford et al., 2005). Manganese oxihydroxides precipitation, below the aerobic layer of sediments, is a well known process (Calvert and Price, 1972). The presence of Mn oxihydroxides in GoL sediment is supported by the various peaks in sedimentary Mn profiles (Fig. S2b). The multi-peak profile in core L and the highest Mn concentration below $7 \mathrm{~cm}$ (not shown) further suggest a prevalence of oxic conditions in the sedimentary surface 
layer. Manganese peak amplitudes in this core were inversely related to the relative $\mathrm{C}_{\text {org }}$ abundance (Fig. $\mathrm{S} 1 b)$. This probably illustrates a deepening of the redox boundary with decreasing OM degradation rates. In this respect, it is also interesting to note the presence, in core I, of a Co peak (and to a lesser extent a Ni peak) coincidental with the large subsurface Mn maximum (Fig. S2b), which attests for the known association of Co with Mn oxides (e.g., Goldberg, 1954). These features, which are even enhanced when considering $\mathrm{Co} / \mathrm{Li}$ and $\mathrm{Ni} / \mathrm{Li}$ vertical profiles (Fig. 6), are likely due to the well known adsorptive properties of Mn oxihydroxides (e.g., Means et al., 1978).

It is finally worth to note the specific behaviour of $\mathrm{Cd}$ in all the cores illustrated by the F4 component (Tables S7a and b), which contains up to $60 \%$ of the variability of Cd data in the continental slope/rise sediments. In the absence of identification of other authigenic phases in these sediments, further hypothesis for identifying the biogeochemical specificity of $\mathrm{Cd}$, such as its large mobility, is speculative.

\subsection{Anthropogenic TES}

\subsubsection{Tracing anthropogenic influence on TEs distributions}

As mentioned previously, for tracing anthropogenic imprints in sedimentary records we used Li as a normalizer element (see section 2.4.). Vertical profiles for $\mathrm{Co} / \mathrm{Li}, \mathrm{Ni} / \mathrm{Li}$ and $\mathrm{V} / \mathrm{Li}$ in both $\mathrm{CdC}$ Canyon cores are rather uniform (except the Co and Ni bumps associated with Mn in core I, see above) (Fig. 6). The behavior of these three elements is similar for lower continental slope/rise sediments (Fig. 6), in spite of higher ratios, due to the dilution by carbonate material. We can conclude that the anthropogenic influence on the distribution of $\mathrm{Co}, \mathrm{Ni}$ and $\mathrm{V}$ is undetectable for the entire $\mathrm{CdC}$ Canyon and the adjacent lower continental slope/rise. Conversely, concentration levels, vertical profiles and isotopic ratios, clearly indicate that significant fractions of $\mathrm{Pb}$ and $\mathrm{Zn}$ in the four cores are of anthropogenic origin (Tables 5 and S6; Figs. 3, 4 and S3). This last statement is consistent with (i) the findings by Radakovitch et al. (2008) who conclude that $\mathrm{Pb}$ and $\mathrm{Zn}$ anthropogenic influence do not decrease from in-shore to off-shore along the continental shelf of the GoL, and with (ii) the $\mathrm{Pb}$ and $\mathrm{Zn}$ enriched surficial sediment compared to deeper layers in the NWM abyssal plain (Angelidis et al., 2011). Intermediate cases are offered by $\mathrm{Cr}, \mathrm{Cd}$ and $\mathrm{Cu}$ which present slightly increasing $\mathrm{TE} / \mathrm{Li}$ ratios from the bottom toward the sediment surface (Fig. 6). However, $\mathrm{Cd}$ and $\mathrm{Cu}$ concentrations do not significantly differ from pristine sediments (Table 4). Further inferences about the anthropogenic impregnation of continental rise sediments by these two elements are uncertain. 
Lead concentration levels and stable $\mathrm{Pb}$ isotopes distribution give clear evidence for anthropogenic impregnation of GoL sediments (Figs. 3 and 4). The range of ${ }^{206} \mathrm{~Pb} /{ }^{207} \mathrm{~Pb}$ values $(1.163$ 1.200, Table 5) is in good agreement with those published by Ferrand et al. (1999) for Lacaze-Duthiers canyon sediments (1.170-1.196) and for continental rise sediments (1.187-1.200). Since the natural ratio for this area is considered around or above 1.19 (Miralles et al., 2006), most of our sediments are more or less contaminated by $\mathrm{Pb}$, the origin of which appears to be mainly $\mathrm{Pb}$ additives to gasoline (Fig. 7). This origin is indeed supported by the statistically significant linear relationships between ${ }^{206 / 207} \mathrm{~Pb}$ and ${ }^{206 / 208} \mathrm{~Pb}$ (Fig. 7) fitting with the European gasoline pool: $1.120-1.165$ and $0.467-0.476$ for ${ }^{206 / 207} \mathrm{~Pb}$ and ${ }^{206 / 208} \mathrm{~Pb}$ respectively (Komarek et al., 2008). Using a $1 / \mathrm{Pb} v s{ }^{206} /{ }^{207} \mathrm{~Pb}$ model, we obtained an anthropogenic $\mathrm{Pb}$ isotopic signature (the end-member for $1 / \mathrm{Pb}=0$ ) varying from 1.132 to 1.152 depending on the core. These values tend to match those obtained from atmospheric aerosol measurements in the last 25 years (1.09 - 1.16 according to references in Ferrand et al., 1999), which reflects the leaded gasoline pollution in Southern Europe. However, the slight difference in ${ }^{206 / 207} \mathrm{~Pb} v \mathrm{~s}$ ${ }^{206 / 208} \mathrm{~Pb}$ slopes (Fig. 7) between cores G and H could suggest another anthropogenic source, which would lower the slope, testifying of a more radiogenic composition of $\mathrm{Pb}$ isotopes in core $\mathrm{H}$. Figure 7 suggests that this other source should have an isotopic signature close to "industrial lead". Evidenced by the isotopic ratio vertical profiles (Fig. 4), the thickness of the layer affected by $\mathrm{Pb}$ contamination varies considerably between cores, a difference that could directly result from different sedimentation rates.

\subsubsection{Chronology, quantification and sources of anthropic $\mathrm{Pb}$ and $\mathrm{Zn}$}

Anthropogenic $\mathrm{Pb}$ maxima were found at $4 \mathrm{~cm}$ in the upper canyon (core $\mathrm{G}$ ), between 5 and $17 \mathrm{~cm}$ in the middle canyon (core $\mathrm{H}$ ) and at the sediment-water interface for lower continental slope/rise (cores I and L). Leaded gasoline was entirely withdrawn from the European Union market in 2000 AD, although it had been banned much earlier in most member states. Figures 6 and 8 report reconstructed chronological profiles for $\mathrm{Pb}$, and its associated isotopic ratios. It appears clearly from canyon cores that anthropogenic $\mathrm{Pb}$ has culminated between 1960 and 1980, the current concentrations being >40\% lower than 30 years ago. Similar distribution is also observed for Zn (Fig. 6), but reduction of contamination level reaches only $20 \%$ for the same period. At the lower continental slope/rise, anthrogenic input the last hundred years is evidenced by the isotopic ratio profiles (Fig. 8). However, the reduction rate of the concentrations within the most recent deposited sediments of these two cores is not visible due to the weak resolution of the chronological records. Our chronology for anthropogenic $\mathrm{Pb}$ deposition is consistent with the reconstructed anthropogenic Pb emission in France since $1800 \mathrm{AD}$ (see Figure 8 in 
Ferrand et al., 1999) and with a previous reconstitution by Miralles et al. (2006): Pb concentrations in gasoline have been maximal in the seventies, and since then have dramatically decrease between 1980 and $1990 \mathrm{AD}$, before being banned in $2000 \mathrm{AD}$. In the four cores the $\mathrm{Pb} / \mathrm{Li}$ and ${ }^{206} \mathrm{~Pb} /{ }^{207} \mathrm{~Pb}$ ratios are converging in the surface sediment on values that reflect the current background atmospheric contamination level of the coastal sea and the surrounding catchment basins, 0.7 and 1.18, respectively (Figs. 6 and 8). The simultaneous occurrence of anthropogenic $\mathrm{Zn}$ and $\mathrm{Pb}$ is puzzling. There is no indication for $\mathrm{Zn}$ in gasoline additives; anthropogenic $\mathrm{Zn}$ is rather emitted into the atmosphere during burning of coal and heavy oils, by non ferrous metal industry and waste incineration. Our results suggest that anthropogenic $\mathrm{Zn}$ started to decline in the mid-sixties (Fig. 6). However, air emission records (CITEPA, 2012) indicate that, due to technological changes, Zn discharges in French atmosphere have been reduced by a factor of eight since 1990 .

Anthropogenic fractions of $\mathrm{Pb}$ can be estimated for each layer based on its ${ }^{206} \mathrm{~Pb} /{ }^{207} \mathrm{~Pb}$ ratio and an assumed natural value of 1.20 -similar to that found in the deep basin- (Angelidis et al., 2011). Anthropogenic $\mathrm{Pb}$ inventories are calculated by summing all layers and amount respectively to 142 $\mu \mathrm{g} . \mathrm{cm}^{-2}$ (core G), $200 \mu \mathrm{g} . \mathrm{cm}^{-2}$ (core H), $17.4 \mu \mathrm{g} . \mathrm{cm}^{-2}$ (core I), and $11.3 \mu \mathrm{g} . \mathrm{cm}^{-2}$ (core L). Combining these values with the ${ }^{210} \mathrm{~Pb}$ inventories (Table 3), and assuming that the $0.174 \mathrm{~Bq} \mathrm{~cm}^{-2}$ and $\mathrm{Pb}$ flux in core $\mathrm{L}$ result entirely from direct atmospheric deposition (see section 2.6.), we estimated the $\mathrm{Pb}$ fraction associated with atmospheric deposition for the other cores and found 17,7 and $61 \%$ for cores $\mathrm{G}, \mathrm{H}$ and I. It appears that the $\mathrm{CdC}$ Canyon is a place of large anthropogenic $\mathrm{Pb}$ accumulation (up to $200 \mu \mathrm{g} \mathrm{cm}^{-2}$ in the middle of the canyon, core H), much larger than those observed for similar water depth (700$1700 \mathrm{~m}$ ) on the open slope of the eastern GoL, where mean anthropogenic $\mathrm{Pb}$ accumulation was $110 \pm 7$ $\mu \mathrm{g} \mathrm{cm}^{-2}$ (Miralles et al 2006). The direct $\mathrm{Pb}$ atmospheric deposition on the total $\mathrm{Pb}$ accumulated decreases from $24 \mu \mathrm{g} \mathrm{cm}^{-2}$ from the upper part of the canyon (core G) to $11 \mu \mathrm{g} \mathrm{cm}^{-2}$ seaward (core L). Nevertheless, the calculated inventory for core $\mathrm{H}$ is under-estimated since the recorded deposition (34 $\mathrm{cm}$ of sediment thickness) is limited to the last 120 years.

\section{Conclusions and summary}


Our results on TEs distributions in surface and resuspended sediments of the GoL shelf, and sediments cores from the $\mathrm{CdC}$ Canyon and adjacent lower continental slope and rise allow the following conclusions:

- $\mathrm{Cr}, \mathrm{Ni}, \mathrm{V}, \mathrm{Zn}, \mathrm{Cu}$ and $\mathrm{Pb}$ in the GoL shelf sediments are associated with clay minerals mainly from riverine origin, whereas $\mathrm{Ag}$ and $\mathrm{Cd}$ are associated with $\mathrm{OM}$. The Rhone prodelta sediments are highly contaminated with $\mathrm{Ag}, \mathrm{Cd}, \mathrm{Cu}, \mathrm{Pb}$ and $\mathrm{Zn}$. Anthropogenic $\mathrm{Cd}$ and $\mathrm{Ag}$ likely originate from fertilizers and urban sewages respectively.

- Hydrodynamic sorting of settling particles at the head of the CdC Canyon during a cascading event affects TE composition of the material transported along the canyon. Coarse carbonate material associated with dense shelf water cascading processes is slightly impoverished in TEs compared to the clays of the nepheloid layer and organic-rich particles typically transported during normal conditions (e.i., in the absence of strong dynamical event such as storms or cascadings).

- Trace elements are hosted by different sediment fractions. $\mathrm{Co}, \mathrm{Cu}, \mathrm{Cr}, \mathrm{Ni}$ and $\mathrm{V}$ are associated with clay, whereas $\mathrm{Ag}, \mathrm{Cu}$ and $\mathrm{Pb}$ are associated with $\mathrm{OM}$ in both canyon and continental slope/rise sediments; $\mathrm{Cd}, \mathrm{Cr}$, and $\mathrm{Zn}$ are also associated with $\mathrm{OM}$ in canyon sediments. Carbonaceous plankton appears to be an especially efficient scavenger for $\mathrm{Ag}$, whereas $\mathrm{Cr}, \mathrm{V}, \mathrm{Zn}$ and $\mathrm{Pb}$ are diluted by biogenic carbonate. An authigenic Mn oxihydroxides fraction is enriched with Co and Ni.

- On continental slope sediments, Ag is strongly associated with carbonaceous planktonic remains, and its mobilization from sediment seems also occur.

- Anthropic $\mathrm{Pb}$ and $\mathrm{Zn}$ are observed from the Rhone prodelta to the continental rise sediments. Anthropogenic $\mathrm{Pb}$ peaked between 1960 and 1980, with current concentrations being >40\% lower than 30 years ago. A similar chronology is observed for $\mathrm{Zn}$ but the reduction of the contamination level reaces only $20 \%$ during the same period. With an inventory of $200 \mu \mathrm{g} \mathrm{cm}^{-2}$, the middle part of the $\mathrm{CdC}$ Canyon is the place of a large anthropogenic $\mathrm{Pb}$ accumulation. At the most distal part of the continental rise anthropogenic $\mathrm{Pb}$ accumulation is estimated around $10 \mu \mathrm{g} \mathrm{cm}^{-2}$, and originates from direct atmospheric deposition.

Finally, our results confirm that most of the trace element contamination on the GoL shelf is from riverine sources and the impact is most visible in the Rhone prodelta sediments. This shelf sediment contamination remains visible for $\mathrm{Ag}, \mathrm{Pb}$ and $\mathrm{Zn}$ along the route towards $\mathrm{CdC}$ Canyon including its head. Trace elements are exported down the $\mathrm{CdC}$ Canyon, with maximum fluxes during 
cascading events. The middle part of the canyon is a site of anthropogenic TE accumulation, with a maximum anthropogenic contribution dating back to 1960-70 decade.

\section{Acknowledgements}

This research has been funded by HERMIONE project (www.eu-hermione.net), a collaborative project under the European Commission's Framework Seven Program (Contract $N^{\circ}$ 226354) and by ONR (Contract $N^{\circ}$ N00014-04-1-0379). Thanks are due to D. Auger and E. Rozuel who performed elementary analyses. 


\section{References}

Algeo, T.J., Maynard, J.B. 2004. Trace-element behavior and redox facies in core shales of Upper Pennsylvanian Kansas-type cyclothems. Chem. Geol., 206: 289- 318.

Algeo, T.J., Lyons, T.W. 2006. Mo-total organic carbon covariation in modern anoxic marine environments: Implications for analysis of paleoredox and paleohydrographic conditions. Paleoceanography, 21, PA1016, doi:10.1029/2004PA001112, 2006

Aloupi, M., Angelidis, M.O. 2001. Normalization to lithium for the assessment of metal contamination in coastal sediment cores from the Aegean Sea, Greece. Mar. Environ. Res., $52: 1-12$

Angelidis, M.O., Radakovitch, O., Veron, A., Aloupi, M., Heussner, S., Price, B. 2011. Anthropogenic metal contamination and sapropel imprints in deep Mediterranean sediments. Mar. Pollut. Bull., 62: 1041-1052.

Appleby P.G., Oldfield F. 1978. The calculation of Lead-210 dates assuming a constant rate of supply of unsupported lead-210 to sediment. Catena, $5: 1-8$.

Barnett P.R.O., Watson J., Connelly D. 1984. A multiple corer for taking virtually undisturbed samples from shelf, bathyal and abyssal sediments. Oceanol. Acta, 7: 399-408.

Belicka, L.L., Macdonald, R.W., Harveya, H.R. 2009. Trace element and molecular markers of organic carbon dynamics along a shelf-basin continuum in sediments of the western Arctic Ocean. Mar. Chem., $115: 72-85$.

Böning, P., Brumsack, H.-J., Schnetger, B., Grunwald, M. 2009. Trace elements signatures of Chilean upwelling sediments at $\sim 36^{\circ}$ S. Mar. Geol., 259: 112-121

Bourgeois, S., Pruski, A., Sun, M.Y., Buscail, R., Lantoine, F., Kerhervé, P., Vétion, G., Rivière, B., Charles, F. 2011. Distribution and lability of land-derived organic matter in the surface sediments of the Rhône prodelta and the adjacent shelf (Mediterranean Sea, France): a multi-proxy study. Biogeosciences, 8: 3107-3125.

Bourrin, F., Monaco, A., Aloisi, J.C., Sanchez-Cabessa, J.A., Lofi, J., Heussner, S., Durrieu de Madron, X., Jeanty, G., Buscail, R., Saragoni, G. 2007. Last millennia sedimentary record on a micro-tidal, low-accumulation prodelta (Têt, NW Mediterranean). Mar. Geol., 243 : 77-96 
Buscail, R. Ambatsian, P., Monaco, A., Bernat, M. 1997. ${ }^{210} \mathrm{~Pb}$, manganese and carbon: indicators of focusing processes on the northwestern Mediterranean continental margin. Mar. Geol., 137: 271-286.

Calvert, S.E., Price, N.B. 1972. Diffusion and reaction profiles of dissolved manganese in the pore waters marine sediments. Earth, Planet. Sci. Lett., 16: 245-249.

Canals, M., Puig, P., Durrieu de Madron, X., Heussner, S., Palanques, A., Fabres, J., 2006. Flushing submarine canyons. Nature, 444: 354-357.

Cathalot, C., Rabouille, C., Pastor, L., Deflandre, B., Viollier, E. , Buscail, R. , Grémare, A. , Treignier, C. , Pruski, A. 2010. Temporal variability of carbon recycling in coastal sediments influenced by rivers : assessing the impact of flood inputs in the Rhône River prodelta. Biogeosciences, 7: 1187-1205.

Cauwet, G., Gadel, F., De Souza Sierra, M.M., Donard, O., Ewald , M. 1990. Contribution of the Rhône river to organic inputs to the northwestern Mediterranean sea. Cont. Shelf Res., 10: 1025-1037.

Chiffoleau, J.F., Auger, D., Boutier, B., Rozuel E., Truquet, I. 2004. Dosage de certains métaux dans les sédiments et la matière en suspension par absorption atomique. Méthodes d'Analyses en milieu marin. Editions Ifremer, BP 70, F-29280 Plouzané, ISSN 1637-1844.

CITEPA. 2012. www.citepa.org

Crusius, J., Thomson, J. 2003. Mobility of authigenic Rhenium, Silver and Selenium during post depositional oxidation in marine sediments. Geochim. Cosmochim. Acta., 67: 265-273.

De Stigter, H.C., Boer, W., de Jesus Mendes, P.A., Jesus, C.C., Thomsen, L., van den Bergh, G.D., van Weering, T.C.E., 2007. Recent sediment transport and deposition in the Nazare' canyon, Portuguese continental margin. Mar. Geol., 246: 144-164.

DeGeest, A.L., Mullenbach, B.L., Puig, P., Nittrouer, C.A., Drexler, T.M., Durrieu de Madron, X., Orange, D.L. 2008. Sediment accumulation in the western Gulf of Lions, France: The role of Cap de Creus Canyon in linking shelf to slope sediment dispersal systems. Cont. Shelf Res., 28: 2031-2047.

Durrieu de Madron, X., Abassi, A., Heussner, S., Monaco, A., Aloisi, J.C., Radakovitch, O., Giresse, P., Buscail, R., Kerherve, P. 2000. Particulate matter and organic carbon budgets for the Gulf of Lions (NW Mediterranean). Oceanol. Acta, 23: 717-730. 
Durrieu de Madron, X., Wiberg, P., Puig, P., 2008. Sediment dynamics in the Gulf of Lions: the impact of extreme events. Introduction special issue. Cont. Shelf Res., 28: 1867-1876.

Elderfield, H., Bertram, C.J. and Erez, J. 1996. A biomineralization model for the incorporation of trace elements into foraminiferal calcium carbonate. Earth, Planet. Sci. Lett., 142: 409-423.

Fanget, A.-S., Bassetti, M.-A., Arnaud, M., Chiffoleau, J.-F., Cossa, D., Goineau, A., Fontanier, C., Buscail, R., Jouet, G., Maillet, G.M., Negri, A., Dennielou, B., Berné, S. 2013. Historical evolution and extreme climate events during the last 400 years on the Rhone prodelta (NW Mediterranean). Mar. Geol., 346: 375-391.

Ferrand, J.-L., Hamelin, B., Monaco, A. 1999. Isotopic tracing of anthropogenic Pb inventories and sedimentary fluxes in the Gulf of Lions (NW Mediterranean sea). Cont. Shelf Res., 19: 23-47.

Ferrand, E., Eyrolle, F., Radakovitch, O., Provansal, M. Dufour, S., Vella, C., Raccasi, G., Gurriaran, R. 2012. Historical levels of heavy metals and artificial radionuclides reconstructed from overbank sediment records in lower Rhone River (South-East France). Geochim. Cosmochim. Acta, 82: 163-182.

Gairoard, S., Radakovitch, O., Eyrolle, F., Ludwig, W., Cossa, D. 2012. Flux de matière solides et liquides des basins versants français à la Mer Méditerranée: Etat des connaissances et recommandations pour un suivi optimisé. Publication CEREGE pour l'AERMC. Sept. 2012.

Gobeil, C., Silverberg, N., Sundby, B., Cossa, D. 1987. Cadmium diagenesis in Laurentian Trough sediments. Geochim. Cosmochim. Acta, 51: 589-596.

Gobeil, C., MacDonald, R.W., Sundby, B. 1997. Diagenetic separation of cadmium and manganese in siboxic continental margin sediments. Geochim. Cosmochim. Acta, 61: 4647-4654.

Goldberg, E.D. 1954. Marine geochemistry1: Chemical scavenging of the sea. J. Geology, 62: 249-265.

Guillen, J., Bourrin, F., Palanques, A., Durrieu de Madron, X., Puig, P., Buscail, R. 2006. Sediment dynamics during wet and dry storm events on the Têt inner shelf (SW Gulf of Lions). Mar. Geol., 234: 129-142.

Heimbürger, L.-E., Cossa, D., Thibodeau, B., Khripounoff, A., Mas, V., Chiffoleau, J.-F., Schmidt, S., Migon, C. 2012. Natural and anthropogenic trace metals in sediments of the Ligurian Sea (Northwestern Mediterranean). Chem. Geol., 291: 141-151. 
Heussner, S., Durrieu de Madron, X., Calaffat, A., Canals, M., Carbonne, J., Delsaut, N., Saragoni, G. 2006. Spatial and temporal variability of downward particle fluxes on a continental slope: lessons from an 8-yr experiment in the Gulf of Lions (NW Mediterranean). Mar. Geol., 234: 63-92.

Hickey, B.M., Baker, E.T., Kachel, N., 1986. Suspended particle movement in and around Quinault Submarine Canyon. Mar. Geol.,71: 35-83.

Huang, J., Deokchoi, H., Hopke P., Holsen, T. 2010. Ambient Mercury Sources in Rochester, NY: Results from Principle Components Analysis (PCA) of Mercury Monitoring Network Data. Environ. Sci. Technol. 44: 8441-8445.

Jackson, J. E. 2003. A User's Guide to Principal Components. Wiley Series in Probability and Statistics. J. Wiley and Sons. 592 pages.

Kersten, M., Smedes, F. 2002. Normalization procedures for sediment contaminants in spatial and temporal trend monitoring. J. Environ. Monitor., 4: 109-115.

Kim, B., Park C.-S., Murayama, M., Hochella, M.F. 2010a. Discovery and Characterization of Silver Sulfide Nanoparticles in Final Sewage Sludge Products. Environ. Sc. Technol., 44: 7509-7514.

Kim, J.H., Zarzycka, B., Buscail, R., Peterse, F., Bonnin, J., Ludwig, W., Schouten, S., Sinninghe- Damsté, J.S. 2010 b. Contribution of river-borne soil organic carbon to the Gulf of Lions (NW Mediterranean). Limnol. Oceanogr., 55: 507-518.

Kim, J.H., Buscail, R., Bourrin, F., Palanques, A., Sinninghe Damtsé, J.S., Bonnin, J., Schouten, S. 2009. Transport and deposition processes of soil organic matter during wet and dry storms on the Têt inner shelf (NW Mediterranean). Palaeogeogr., Palaeoclim., Palaeoecol., 273: 228-238.

Komarek, M., Ettler, V., Chrastny, V., Mihaljevic, M. 2008. Lead isotopes in environmental sciences: A review. Environ. Int., 34: 562-577.

Lanceleur, L., Schäfer, J., Chiffoleau, J.-F., Blanc, G., Auger, D., Renault, S., Baudrimont, M., Audry, S. 2011. Long-term records of cadmium and silver contamination in sediments and oysters from the Gironde fluvial-estuarine continuum - Evidence of changing silver sources. Chemosphere, 85: 2991305 . 
Lastras, G., Canals, M., Urgeles, R., Amblas, D., Ivanov, M., Droz, L., Dennielou, B., Fabrès, J., Schoolmeester T., Akhetzhanov A., Orange D., Garcia-Garcia A. 2007. A walk down the Cap de Creus canyon, Northwestern Mediterranean Sea: Recent processes inferred from morphology and sediment bedforms. Mar. Geol., 246: 176-192.

Li, Y.-H. 2000. A compendium of geochemistry: from solar nebula to human brain. Princeton University Press, Princeton, New Jersey, ISBN 0-691-00938-4.

Loring, D.H. 1990. Lithium- A new approach for the granulometric normalization of trace metal data. Mar. Chem., 29: 155-168.

Loring, D.H., Rantala, R.T.T. 1990. Sediments and suspended particulate matter: total and partial methods of digestion. ICES Techniques in Marine Environmental Sciences, 9: 14 p.

Maurer, D., Robertson, G. Gerlinger, T., Grossett, R. 1996. Organic contaminants in sediments of the Newport Submarine Canyon, California and the adjacent shelf. Water Environ. Res., 68: 1024-1036.

Means, J.L., Crerar, D.A. Borcsik, M.P. 1978. Adsorption of Co and selected actinides by Mn nd Fe oxides in soils and sediments. Geochim. Cosmochim. Acta, 42: 1763-1773.

Miralles J., Radakovitch O., Aloisi J.-C. 2005. ${ }^{210} \mathrm{~Pb}$ sedimentation rates from the Northwestern Mediterranean margin. Mar. Geol., 261: 155-167.

Miralles J., Veron A., Radakovitch O., Deschamps P., Tremblay P., Hamelin B. (2006) Atmospheric lead fallout over the last century recorded in Gulf of Lions sediments (Mediterranean Sea). Mar.Pollut. Bull., 52 : 1364-1371.

Monaco, A., Durrieu de Madron, X., Radakoitch, O., Heussner, S., Carbonne, J. 1999. Origin and variability of downward biogeochemical fluxes on the Rhône continental margin (NW Mediterranean). Deep Sea Res. I, 46: 1483-1511.

Moreford, J.L. and Emerson, S. 1999. The geochemistry of redox sensitive trace meats in sediments. Geochim. Cosmochim. Acta, 63: 1735-1750.

Morford, J.L., Emerson, S.R., Breckel, E.J., Kim, S.H. 2005. Diagenesis of oxyanions (V, U, Re, and Mo) in pore waters and sediments from a continental margin. Geochim. Cosmochim. Acta, 69: 50215032. 
Morford, J.L., Kalnejais, L.H., Helman, P., Yen, G., Reinard, M. 2008. Geochemical cycling of silver in marine sediment along an offshore transect. Mar. Chem., 110: 77-88.

Nozaki, Y. 2001. Element distribution overview. Encyclopedia of Ocean Sciences, Vol. 2 (Steele, J., Thorpe, S., Turekian, K. K., eds.), 840-845, Academic Press, San Diego.

Ogston, A., Drexler, T., Puig, P., 2008. Sediment delivery, resuspension, and transport in two contrasting canyon environments in the southwest Gulf of Lions. Cont. Shelf Res., 28: 2000-2016.

Palanques, A., Martin, J., Puig, P., Guillén, J., Company, J.B., Sarda, F. 2006. Evidence of sediment gravity flows induced by trawling in the Palamós (Fonera) submarine canyon (northwestern Mediterranean). Deep-Sea Res. I, 53: 201-214.

Palanques, A., Masqué, P., Puig, P., Sanchez-Cabeza, J.A., Frignani, M., Alvisi, F. 2008. Anthropogenic trace metals in the sedimentary record of the Llobregat continental shelf and adjacent Foix Submarine Canyon (northwestern Mediterranean). Mar. Geol., 248: 213-227.

Palanques, A., Puig, P., Durrieu de Madron, X., Sanchez-Vidal, A., Pasqual, C., Martín, J., Calafat, A., Heussner, S., Canals, M. 2012. Sediment transport to the deep canyons and open-slope of the western Gulf of Lions during the 2006 intense cascading and open-sea convection period. Progr. Oceanogr., 106: $1-15$.

Pastor, L., Cathalot, C., Deflandre, B., Viollier, E., Soetaert, K., Meysman, F. J. R., Ulses, C., Metzger, E., Rabouille, C. 2011. Modeling biogeochemical processes in sediments from the Rhône River prodelta area (NW Mediterranean Sea). Biogeosciences, 8: 1351-1366.

Petersen, W., Wallmann, K., Li, P.L. 1995. Exchange of trace-elements at the sediment-water interface during early diagenesis processes. Mar. Freshwat. Res., 46: 19-26.

Puig, P., Palanques, A., Sanchez-Cabeza, J.A., Masqué, P. 1999. Heavy metals in particulate matter and sediments in the southern Barcelona sedimentation system (North-western Mediterranean). Mar. Chem., 63: 311-329.

Puig, P., Ogston, A.S., Mullenbach, B.L., Nittrouer, C.A., Sternberg, R.W. 2003. Shelf-to-canyon sediment-transport processes on the Eel continental margin (northern California). Mar. Geol., 193: 129-149. 
Puig, P., Palanques, A., Orange, D.L., Lastras, G., Canals, M. 2008. Dense shelf water cascades and sedimentary furrow formation in the Cap de Creus Canyon, northwestern Mediterranean Sea. Cont. Shelf Res., 28: 2017-2030.

Puig, P., Durrieu de Madron, X., Salat, J., Schroeder, K., Martín, J., Karageorgis, A.P., Palanques, A., Roullier, F., Lopez-Jurado, J.L., Emelianov, M., Moutin, T., Houpert, L. 2013. Thick bottom nepheloid layers in the western Mediterranean generated by deep dense shelf water cascading. Progr. Oceanogr., 111: 1-23.

Puig, P., Palanques, A., Martín, J. 2014. Contemporary Sediment-Transport Processes in Submarine Canyons. Annu. Rev. Mar. Sci., 6: 53-77.

Radakovitch O., Heussner S. 1999 Fluxes and balance of ${ }^{210} \mathrm{~Pb}$ on the Bay of Biscay continental margin (northeastern atlantic). Deep-Sea Res. II, 46/10-11, 2175-2203.

Radakovitch, O., Roussiez, V., Ollivier, P., Ludwig, W., Grenz, C., Probst, J.-L. 2008. Input of particulate heavy metals from rivers and associated sedimentary deposits on the Gulf of Lion continental shelf. Est. Ctl. Shelf Sci., 77: 285-295.

Révillon, S., Jouet, G., Bayon, G., Rabineau, M., Dennielou, B., Hémond, C., Berné, S. 2011. The provenance of sediments in the Gulf of Lions, western Mediterranean Sea. Geochemistry, Geophysics, Geosystems, 12: Q08006, 20 PP. doi:10.1029/2011GC003523

Richter, T.O., de Stigter H.C., Boer W., Jesus C.C., van Weering T.C.E. 2009. Dispersal of natural and anthropogenic lead through submarine canyons at the Portuguese margin. Deep-Sea Res. I, 56: 267282.

Roussiez, V., Ludwig, W., Probst, J.-L., Monaco, A. 2005. Background levels of heavy metals in surficial sediments of the Gulf of Lions (NW Mediterranean Sea): An approach based on ${ }^{133} \mathrm{Cs}$ normalization and lead isotope measurements. Environ. Pollut., 138: 167-177.

Roussiez, V., Ludwig, W., Monaco, A., Probst, J.-L., Bouloubassi, I., Buscail, R., Saragoni, G. 2006. Sources and sinks of sediment-bound contaminants in the Gulf of Lions (NW Mediterranean sea) : A multi-tracer approach. Cont. Shelf Res., 26: 1843-11857.

Roussiez, V., Heussner S., Ludwig W., Radakovitch O., Durrieu de Madron X., Guieu C., Probst, J.L, Monaco A., Delsaut N. 2012. Impact of oceanic floods to particulate metal inputs to coastal and deep sea environments: a case study in the Northwest Mediterranean. Cont. Shelf Res., 45: 15-26. 
Salat, J., Puig, P., and Latasa, M. 2010. Violent storms with the sea: dense water formation episodes in the NW Mediterranean. Adv. Geosci., 26: 53-59.

Salvado, J.A, Grimalt, J.O, Lopez, J.F., Durrieu de Madron, X., Heussner, S., Canals, M. 2012a. Transformation of PBDE mixture during sediment transport and resuspension in marine environments (Gulf of Lions, NW Mediterranean Sea). Environ. Pollut., 168: 87-95.

Salvado, J.A, Grimalt, J.O, Lopez, J.F., Palanque, A., Heussner, S., Pasqual, C., Sanchez-Vidal, A., Canals, M. 2012b. Role of dense Shelf Water cascading in the Transfer of Organochlorine Compounds to the Open Marine Waters. Environ. Sci. Technol., 46: 2624-2632.

Sanudo-Wilhelmy, S.A., Flegal, A.R. 1992. Anthropogenic silver in the Southern California Bight: a new tracer of sewage in coastal waters. Environ. Sci. Technol., 26: 2147-2151.

Stabholz, M., durrieu de Madron, X., Canals, M., Khripounoff, A., taupier-Letage, I., testor, P., Heussner, S., Kerhervé, P., Delsaut, N., Houpert, L., Lastras, G., Dennielou, B. 2013. Impact of open-ocean convection on particle fluxes and sediment dynamics in the deep margin of the Gulf of Lions. Biogeosciences, 10: 1097-1116.

Sundby, B., Martinez, P., Gobeil, C. 2004. Comparative geochemistry of cadmium, rhenium, and molybdenum in continental margin sediments. Geochim. Cosmochim. Acta, 68: 2485-2493.

Tesi, T., Puig, P., Palanques, A., Goñi, M.A. 2010. Lateral advection of organic matter in cascadingdominated submarine canyons. Progr. Oceanogr., 84: 185-203.

Tribovillard, N., Algeo, T.J., Lyons, T. Riboulleau, A. 2006. Trace metals as paleoredox and paleoproductivity proxies: An update. Chem. Geol., 232: 12-32.

Turekian, K.K., Katx, A., Chan, L. 1973. Trace element trapping in pteropods tests. Limnol. Oceanogr., 18: $240-249$.

Van der Weijden, C.H., Reichart, G.-J., van Os, B.J.H. 2006. Sedimentary trace elements records over the last $200 \mathrm{kyr}$ from within and below the northern Arabian Sea oxygen minimum zone. Mar. Geol., 231: 69-88.

World Health Organisation (WHO) 1992. Environmental Health Criteria 134 - Cadmium International Programme on Chemical Safety (IPCS) Monograph. 


\section{List of tables}

Table 1. Organic content $\left(\mathrm{C}_{\mathrm{org}}, \mathrm{C} / \mathrm{N}\right)$, carbonate, major elements $(\mathrm{Al}, \mathrm{Fe}, \mathrm{Mn})$ and $\mathrm{Li}$ (mean \pm standard deviation, number of determination in brackets $)$ of the surface sediments $(0-1 \mathrm{~cm})$ from the Rhône prodelta (RD), Gulf of Lions shelf (SH), Cap de Creus Canyon head (HD), moored sediment trap samples collected at the canyon head (ST), Cap de Creus Canyon (cores G and H) and adjacent lower continental slope (core I) and rise (core L).

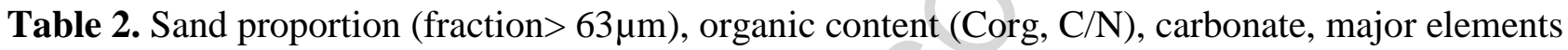
$(\mathrm{Al}, \mathrm{Fe})$ and $\mathrm{Li}$ (mean \pm standard deviation, number of determination in brackets) for the sediments cores collected in the Cap de Creus Canyon (cores G and H) and adjacent lower continental slope (core I) and rise (core L).

Table 3. Sedimentation rates, accumulation rates and ${ }^{210} \mathrm{~Pb}_{\mathrm{ex}}$ inventories for the different cores and layers (G, H, I and L).

Table 4. Mean trace element composition (mean \pm standard deviation, number of determination in brackets) of the surface sediments $(0-1 \mathrm{~cm})$ from the Rhone prodelta (RD), Gulf of Lions shelf (SH), Cap de Creus canyon head (HD), moored sediment trap samples collected at the canyon head (ST), Cap de Creus Canyon (cores $\mathrm{G}$ and $\mathrm{H}$ ) and adjacent lower continental slope (core I) and rise (core L). EUC reefers to average composition of Earth's upper crust (values compiled by Li, 2000). (*) Coarse ( $>63$ $\mu \mathrm{m})$ material constitutes more than $50 \%$ of the sediment mass.

Table 5. Summary statistics for $\mathrm{Pb}$ concentration and its stable isotopic ratios in the Cap de Creus Canyon (cores $\mathrm{G}$ and $\mathrm{H}$ ) and adjacent lower continental slope/rise (cores I and L) sediments. Mean \pm standard deviation, (n) and range (min-max).

Table 6. Mean enrichment factors ( \pm standard deviation) for clay associated TEs $\left([\mathrm{TE} / \mathrm{Li}]_{\text {sample }} /\right.$ $\left.[\mathrm{TE} / \mathrm{Li}]_{\text {background }}\right)$ for the surface sediments $(0-1 \mathrm{~cm})$ compared to preindustrial layers (see text). Rhone prodelta (RD), Gulf of Lions shelf (SH), Cap de Creus canyon head (HD), moored sediment trap samples collected at the canyon head (ST). $\mathrm{ST}_{\text {fine }}$ refers to pre- and post-cascading conditions, whereas $\mathrm{ST}_{\text {coarse }}$ refers to the cascading event in March 2005. Preindustrial mass ratios: $\mathrm{Cr} / \mathrm{Li}=1.16, \mathrm{Cu} / \mathrm{Li}=$ $0.39, \mathrm{Ni} / \mathrm{Li}=0.69, \mathrm{~Pb} / \mathrm{Li}=0.37, \mathrm{~V} / \mathrm{Li}=1.70$ and $\mathrm{Zn} / \mathrm{Li}=1.33$. Standard deviation $=\mathrm{Q}\left(\left(\mathrm{SD}_{\mathrm{A}}^{2} / \mathrm{A}^{2}\right)+\right.$ $\left.\left(\mathrm{SD}_{\mathrm{B}}{ }^{2} / \mathrm{B}^{2}\right)\right)^{1 / 2}$, with $\mathrm{Q}=\mathrm{A} / \mathrm{B}, \mathrm{SD}_{\mathrm{A}}$ and $\mathrm{SD}_{\mathrm{B}}$ the standard deviations on $\mathrm{A}$ (numerator) and $\mathrm{B}$ (denominator). 
Table 1. Organic content $\left(\mathrm{C}_{\mathrm{org}}, \mathrm{C} / \mathrm{N}\right)$, carbonate, major elements $(\mathrm{Al}, \mathrm{Fe}, \mathrm{Mn})$ and $\mathrm{Li}$ (mean \pm standard deviation, number of determination in brackets) of the surface sediments (0-1 cm) from the Rhône prodelta (RD), Gulf of Lions shelf (SH), Cap de Creus canyon head (HD),

moored sediment trap samples collected at the canyon head (ST), Cap de Creus canyon (cores G and H) and adjacent lower continental slope (core I) and rise (core L).

\begin{tabular}{cccccccc}
\hline & $\mathrm{C}_{\text {org }}(\%$ d.w.) & $\mathrm{C} / \mathrm{N}($ atomic ratio) & Carbonate $(\%)$ & $\mathrm{Al}(\%)$ & $\mathrm{Li}\left(\mu \mathrm{g} \mathrm{g}^{-1}\right)$ & $\mathrm{Fe}(\%)$ & $\mathrm{Mn}(\mu \mathrm{g} \mathrm{g})$ \\
\hline $\mathrm{RD}$ & $1.73 \pm 0.17(4)$ & $8.8 \pm 0.6(4)$ & $22.5 \pm 5.5(4)$ & $5.33 \pm 0.21(4)$ & $51.0 \pm 2.5(4)$ & $3.06 \pm 0.09(4)$ & $609 \pm 27(4)$ \\
$\mathrm{SH}$ & $0.74 \pm 0.23(18)$ & $7.3 \pm 0.9(18)$ & $17.6 \pm 6.4(12)$ & $5.21 \pm 0.79(19)$ & $52.3 \pm 9.6(15)$ & $2.91 \pm 0.55(19)$ & $591 \pm 170(15)$ \\
$\mathrm{HD}$ & $0.62 \pm 0.27(3)$ & $7.2 \pm 1.2(3)$ & $25.9 \pm 6.5(3)$ & $5.10 \pm 0.98(3)$ & $47.6 \pm 8.3(3)$ & $2.75 \pm 0.45(3)$ & $482 \pm 72(3)$ \\
$\mathrm{ST}$ & $1.41 \pm 0.65(25)$ & $7.4 \pm 0.4(25)$ & $21.0 \pm 2.6(23)$ & $6.21 \pm 0.86(23)$ & $55.5 \pm 13.2(23)$ & $3.06 \pm 0.60(23)$ & $817 \pm 304(23)$ \\
$\mathrm{G}$ & $0.71 \pm 0.07(2)$ & $9.7 \pm 0.5(2)$ & $34.6 \pm 0.9(2)$ & $6.40 \pm 0.20(2)$ & $60.0 \pm 2.5(2)$ & $3.10 \pm 0.13(2)$ & $1250 \pm 98(2)$ \\
$\mathrm{H}$ & $0.74 \pm 0.03(2)$ & $9.6 \pm 0.4(2)$ & $28.2 \pm 0.1(2)$ & $6.11 \pm 0.05(2)$ & $57.9 \pm 1.6(2)$ & $3.10 \pm 0.05(2)$ & $1146 \pm 766(2)$ \\
$\mathrm{I}$ & $0.46 \pm 0.02(2)$ & $10.0 \pm 0.1(2)$ & $580 \pm 5.0(2)$ & $4.53 \pm 0.68(2)$ & $32.4 \pm 0.3(2)$ & $2.22 \pm 0.35(2)$ & $2596 \pm 1473(2)$ \\
$\mathrm{L}$ & $0.39 \pm 0.02(2)$ & $11.2 \pm 1.3(2)$ & $45.0 \pm 1.4(2)$ & $3.60 \pm 0.23(2)$ & $41.4 \pm 7.5(2)$ & $1.95 \pm 0.19(2)$ & $890 \pm 167(2)$ \\
\hline
\end{tabular}


Table 2. Sand proportion (fraction $>63 \mu \mathrm{m}$ ), organic content (Corg, $\mathrm{C} / \mathrm{N}$ ), carbonate, major elements $(\mathrm{Al}, \mathrm{Fe})$ and $\mathrm{Li}(\mathrm{mean} \pm \mathrm{standard}$ deviation, number of determination in brackets) for the sediments cores collected in the Cap de Creus Canyon (cores G and H) and adjacent lower continental slope/rise (cores I and L).

\begin{tabular}{|c|c|c|c|c|c|c|c|}
\hline Core & Sand (\% d.w.) & $\mathrm{C}_{\text {org }}(\%$ d.w. $)$ & $\mathrm{C} / \mathrm{N}$ (atomic ratio) & Carbonate $(\%)$ & $\mathrm{Al}(\%)$ & $\mathrm{Li}\left(\mu \mathrm{g} \mathrm{g}^{-1}\right)$ & $\mathrm{Fe}(\%)$ \\
\hline G & $12.0 \pm 7.5(25)$ & $0.56 \pm 0.08(25)$ & $8.8 \pm 1.0$ & $27.3 \pm 2.4(25)$ & $6.53 \pm 0.24(25)$ & $68.3 \pm 5.5(25)$ & $3.17 \pm 0.18(25)$ \\
\hline $\mathrm{H}$ & $17.2 \pm 12.2(28)$ & $0.65 \pm 0.11(28)$ & $8.9 \pm 1.0$ & $27.9 \pm 0.9(28)$ & $6.49 \pm 0.25(28)$ & $67.1 \pm 4.7(28)$ & $3.18 \pm 0.10(28)$ \\
\hline I & $34.5 \pm 10.2(21)$ & $0.41 \pm 0.03(21)$ & $9.2 \pm 0.9 \quad(21)$ & $41.3 \pm 4.6(21)$ & $4.16 \pm 0.43(21)$ & $37.9 \pm 5.3(21)$ & $2.26 \pm 0.25(21)$ \\
\hline $\mathrm{L}$ & $23.8 \pm 14.9(9)$ & $0.34 \pm 0.09(9)$ & $6.6 \pm 2.0$ & $39.1 \pm 7.6(9)$ & $5.17 \pm 0.43(9)$ & $48.4 \pm 5.1(9)$ & $2.53 \pm 0.22(9)$ \\
\hline
\end{tabular}


Table 3. Sedimentation rates, accumulation rates and ${ }^{210} \mathrm{~Pb}_{\mathrm{ex}}$ inventories for the different cores and layers (G, H, I and $\left.\mathrm{L}\right)$.

\begin{tabular}{|c|c|c|c|c|}
\hline Core & Layer (cm) & Sedimentation rate $\left(\mathrm{cm} \mathrm{a}^{-1}\right)$ & Accumulation rate $\left(\mathrm{g} \mathrm{cm}^{-2} \mathrm{a}^{-1}\right)$ & ${ }^{210} \mathrm{~Pb}_{\mathrm{ex}}$ inventories $\left(\mathrm{Bq} \mathrm{cm}^{-2}\right)$ \\
\hline G & $0.0-10.5$ & 0.19 & 0.26 & 1.033 \\
\hline $\mathrm{H}$ & $2.5-5.5$ & 0.19 & 0.27 & ) \\
\hline $\mathrm{H}$ & $5.5-13.5$ & 0.52 & 0.70 & 2.667 \\
\hline $\mathrm{H}$ & $13.5-19.5$ & 0.18 & 0.26 & \\
\hline $\mathrm{I}$ & $0.0-8.5$ & 0.06 & 0.04 & 0.285 \\
\hline $\mathrm{L}$ & $0.0-5.5$ & 0.02 & 0.04 & 0.174 \\
\hline
\end{tabular}


Table 4. Mean trace element composition (mean \pm standard deviation, number of determination in brackets) of the surface sediments (0-1 cm) from the Rhone prodelta (RD), Gulf of Lions shelf (SH), Cap de Creus canyon head (HD), moored sediment trap samples collected at the canyon head (ST), Cap de Creus Canyon (cores G and H) and adjacent lower continental slope (core I) and rise (core L). EUC reefers to average composition of Earth's upper crust (values compiled by Li, 2000). (*) Coarse (>63 $\mu \mathrm{m})$ material constitutes more than $50 \%$ of the sediment mass.

\begin{tabular}{|c|c|c|c|c|c|c|c|c|c|}
\hline Core & $\operatorname{Ag}\left(\mu g g^{-1}\right)$ & $\mathrm{Cd}\left(\mu \mathrm{g} \mathrm{g}^{-1}\right)$ & $\operatorname{Co}\left(\mu g g^{-1}\right)$ & $\operatorname{Cr}\left(\mu g^{-1}\right)$ & $\mathrm{Cu}\left(\mu \mathrm{g} \mathrm{g}^{-1}\right)$ & $\mathrm{Ni}\left(\mu \mathrm{g} \mathrm{g}^{-1}\right)$ & $\mathrm{Pb}\left(\mu \mathrm{g} \mathrm{g}^{-1}\right)$ & $\mathrm{V}\left(\mu \mathrm{g} \mathrm{g}^{-1}\right)$ & $\mathrm{Zn}\left(\mu \mathrm{g} \mathrm{g}^{-1}\right)$ \\
\hline $\mathrm{RD}$ & $0.66 \pm 0.09$ & $0.34 \pm 0.07$ & $12.9 \pm 0.6(4)$ & $79.6 \pm 3.8(4)$ & $38.5 \pm 3.1(4)$ & $38.6 \pm 2.0(4)$ & $39.7 \pm 3.2(4)$ & $89 \pm 7(4)$ & $131 \pm 10(4)$ \\
\hline $\mathrm{SH}$ & $0.21 \pm 0.11(15)$ & $0.11 \pm 0.02(15)$ & $11.8 \pm 1.7(15)$ & $69.7 \pm 12.0(15)$ & $19.9 \pm 3.9(15)$ & $32.0 \pm 6.2(15)$ & $38.4 \pm 4.9$ & $96 \pm 14(15)$ & $96 \pm 16(15)$ \\
\hline HD & $0.14 \pm 0.05$ & $0.11 \pm 0.02$ & $12.0 \pm 1.6(3)$ & $65.5 \pm 11.9(5)$ & $17.8 \pm 4.6(3)$ & $30.9 \pm 4.2(3)$ & $29.8 \pm 13.3(3)$ & $91 \pm 16(3)$ & $78 \pm 21(3)$ \\
\hline $\mathrm{ST}$ & $0.18 \pm 0.04(23)$ & $0.10 \pm 0.01$ & $15.9 \pm 1.9(23)$ & $76.8 \pm 18.8(23)$ & $27.4 \pm 8.4(23)$ & $37.7 \pm 8.8(23)$ & $39.6 \pm 7.2(23)$ & $106 \pm 26(23)$ & $102 \pm 22(23)$ \\
\hline $\mathrm{G}$ & $0.12 \pm 0.01$ & $0.13 \pm 0.01(2)$ & $16.2 \pm 0.5(2)$ & $85.4 \pm 3.4(2)$ & $29.3 \pm 2.3(2)$ & $50.7 \pm 2.6(2)$ & $46.3 \pm 4.7(2)$ & $108 \pm 3(2)$ & $107 \pm 4(2)$ \\
\hline $\mathrm{H}$ & $0.11 \pm 0.01$ & $0.13 \pm 0.01(2)$ & $16.1 \pm 2.6(2)$ & $82.0 \pm 0.4(2)$ & $27.1 \pm 1.2(2)$ & $47.2 \pm 1.9(2)$ & $42.1 \pm 0.4(2)$ & $104 \pm 1(2)$ & $101 \pm 2(2)$ \\
\hline $\mathrm{I}^{*}$ & $0.11 \pm 0.02$ & $0.07 \pm 0.01(2)$ & $15.2 \pm 3.4(2)$ & $51.2 \pm 5.1(2)$ & $24.4 \pm 2.1(2)$ & $35.4 \pm 4.8(2)$ & $24.4 \pm 0.3(2)$ & $60 \pm 5(2)$ & $51 \pm 2(2)$ \\
\hline $\mathrm{L}$ & $0.16 \pm 0.07$ & $0.12 \pm 0.01$ & $20.8 \pm 0.5(2)$ & $63.2 \pm 9.6(2)$ & $32.2 \pm 4.7(2)$ & $43.9 \pm 7.5(2)$ & $27 . .3 \pm 1.2(2)$ & $74 \pm 12(2)$ & $67 \pm 8(2)$ \\
\hline EUC & 0.05 & 0.1 & $10-18$ & 35 & 25 & $20-56$ & $17-20$ & $60-86$ & 71 \\
\hline
\end{tabular}


Table 5. Summary statistics for Pb concentration and its stable isotopic ratios in the Cap de Creus Canyon (cores $\mathrm{G}$ and $\mathrm{H}$ ) and adjacent lower continental slope (core I) and rise (core L) sediments. Mean \pm standard deviation, (n) and range (min-max).

\begin{tabular}{|c|c|c|c|}
\hline Core & $\mathrm{Pb}\left(\mu \mathrm{g} \mathrm{g}^{-1}\right)$ & ${ }^{206} \mathrm{~Pb} /{ }^{207} \mathrm{~Pb}$ & ${ }^{206} \mathrm{~Pb} /{ }^{208} \mathrm{~Pb}$ \\
\hline $\mathrm{G}$ & $\begin{array}{c}37.2 \pm 13.6(25) \\
20.3-71.4\end{array}$ & $\begin{array}{c}1.184 \pm 0.010(25) \\
1.1625-1.1963\end{array}$ & $\begin{array}{c}0.480 \pm 0.002(25) \\
0.4747-0.4825\end{array}$ \\
\hline $\mathrm{H}$ & $\begin{array}{c}45.9 \pm 5.1(28) \\
37.0-52.5\end{array}$ & $\begin{array}{c}1.180 \pm 0.005(28) \\
1.1729-1.1906\end{array}$ & $\begin{array}{c}0.479 \pm 0.001(28) \\
0.4781-0 . .4816\end{array}$ \\
\hline $\mathrm{I}$ & $\begin{array}{c}19.6 \pm 3.9(18) \\
16.4-24.6\end{array}$ & $\begin{array}{c}1.193 \pm 0.005(21) \\
1.1838-1.2009\end{array}$ & $\begin{array}{c}0.482 \pm 0.001(21) \\
0.4796-0.4837\end{array}$ \\
\hline $\mathrm{L}$ & $\begin{array}{c}22.4 \pm 3.8(9) \\
19.2-26.4\end{array}$ & $\begin{array}{c}1.190 \pm 0.005(9) \\
1.1802-1.1945\end{array}$ & $\begin{array}{c}0.481 \pm 0.001(9) \\
0.4793-0.4823\end{array}$ \\
\hline
\end{tabular}


Table 6. Mean enrichment factors ( \pm standard deviation) for clay associated TEs ([TE/Li $\left.]_{\text {sample }} /[\mathrm{TE} / \mathrm{Li}]_{\text {background }}\right)$ for the surface sediments (0-1 cm) compared to preindustrial layers (see text). Rhone prodelta (RD), Gulf of Lions shelf (SH), Cap de Creus canyon head (HD), moored sediment trap samples collected at the canyon head (ST). ST fine refers to pre- and post-cascading conditions, whereas $\mathrm{ST}_{\text {coarse }}$ refers to the cascading event in March 2005. Preindustrial mass ratios: $\mathrm{Cr} / \mathrm{Li}=1.16, \mathrm{Cu} / \mathrm{Li}=0.39, \mathrm{Ni} / \mathrm{Li}=0.69, \mathrm{~Pb} / \mathrm{Li}$ $=0.37, \mathrm{~V} / \mathrm{Li}=1.70$ and $\mathrm{Zn} / \mathrm{Li}=1.33$. Standard deviation $=\mathrm{Q}\left(\left(\mathrm{SD}_{\mathrm{A}}{ }^{2} / \mathrm{A}^{2}\right)+\left(\mathrm{SD}_{\mathrm{B}}{ }^{2} / \mathrm{B}^{2}\right)\right)^{1 / 2}$, with $\mathrm{Q}=\mathrm{A} / \mathrm{B}, \mathrm{SD}_{\mathrm{A}}$ and $\mathrm{SD}_{\mathrm{B}}$ the standard deviations on A (numerator) and B (denominator).

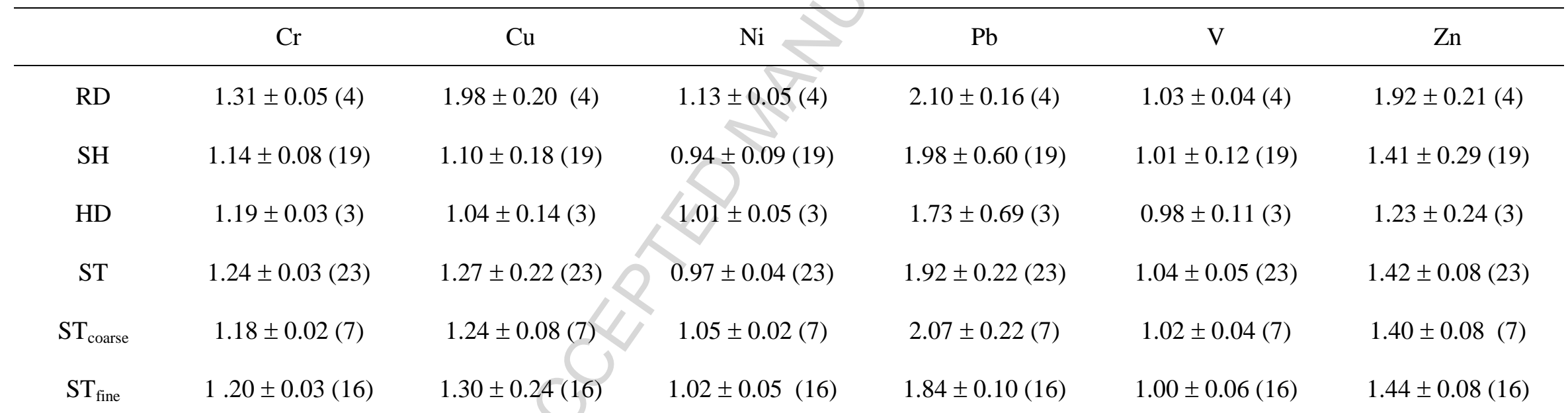




\section{Figure captions}

Figure 1. Sampling locations on the shelf of the Gulf of Lions (GoL), Cap de Creus (CdC) Canyon (cores $\mathrm{G}$ and $\mathrm{H}$ ) and lower continental slope (core I) and rise (core L). RD: Rhone prodelta; SH: GoL shelf; HD: CdC Canyon head; ST: Sediment trap. See table S1 for sampling station coordinates.

Figure 2. Time series of major ( $\mathrm{Al}$, carbonate, $\mathrm{Fe}$ and $\mathrm{C}_{\text {org }}$ ) and trace elements (TE) concentrations in the particles collected in the sediment trap moored at the head of the Cap de Creus Canyon between October 2004 and June 2005.

Figure 3. Vertical profiles of trace element concentrations in the Cap de Creus Canyon (cores G and $\mathrm{H}$ ) and adjacent lower continental slope (core I) and rise (core L) sediments.

Figure 4. Lead isotopic ratios in the Cap de Creus Canyon (cores $\mathrm{G}$ and $\mathrm{H}$ ) and adjacent lower continental slope (core I) and rise (core L) sediments.

Figure 5. Relationships between trace element (TE) to lithium (Li) ratios and organic carbon $\left(\mathrm{C}_{\text {org }}\right)$ in the Cap de Creus Canyon (cores $\mathrm{G}$ and $\mathrm{H}$ ) and adjacent lower continental slope (core I) and rise (core L) sediments.

Figure 6. Vertical profiles of trace element (TE) to lithium (Li) ratios in the Cap de Creus Canyon (cores $\mathrm{G}$ and $\mathrm{H}$ ) and adjacent lower continental slope (core I) and rise (core L) sediments.

Figure 7. Relationships between ${ }^{206} \mathrm{~Pb} /{ }^{208} \mathrm{~Pb}$ and ${ }^{206} \mathrm{~Pb} /{ }^{207} \mathrm{~Pb}$ isotopic ratios in the Cap de Creus Canyon (cores $\mathrm{G}$ and $\mathrm{H}$ ) and adjacent lower continental slope/rise (cores I and L) sediments. Additional ratios, from Komarek et al. (2008) and Ferrand et al. (1999), are provided to identify $\mathrm{Pb}$ sources.

Figure 8. Chronology from $1600 \mathrm{AD}$ to present for ${ }^{206} \mathrm{~Pb} /{ }^{207} \mathrm{~Pb}$ isotopic ratios in the Cap de Creus Canyon (cores $\mathrm{G}$ and $\mathrm{H}$ ) and adjacent lower continental slope/rise (cores I and L) sediments. 


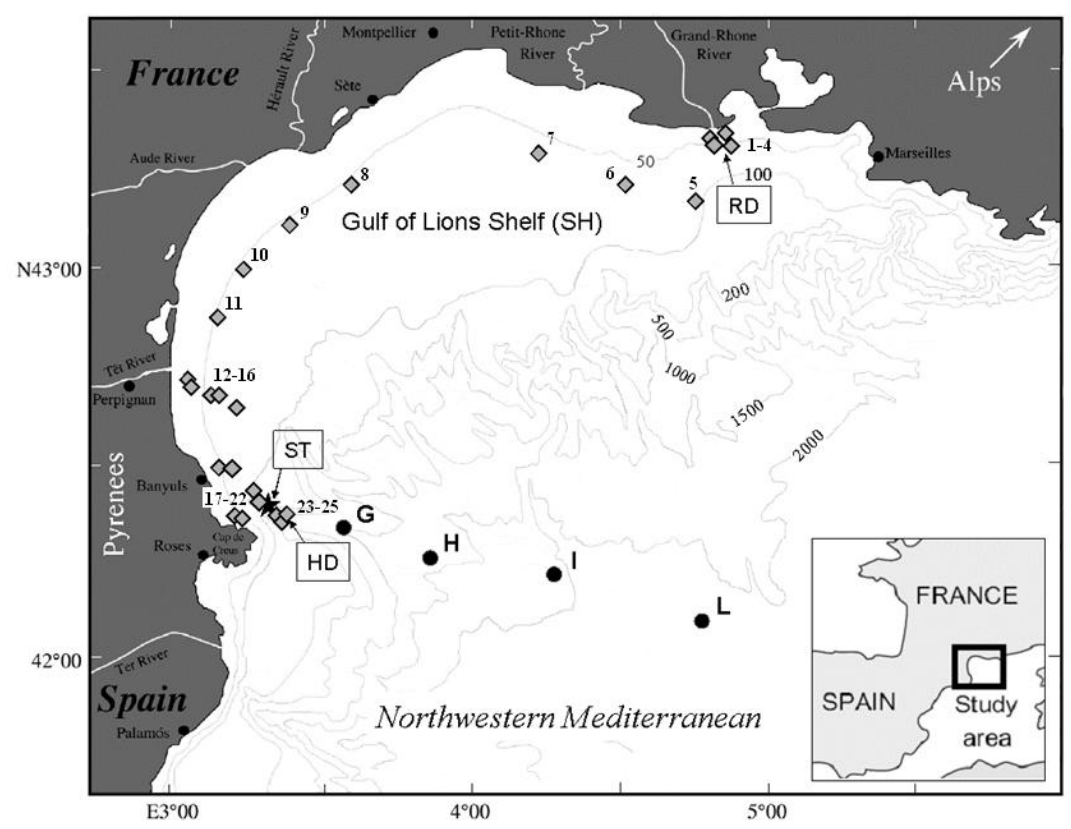

Fig. 1 


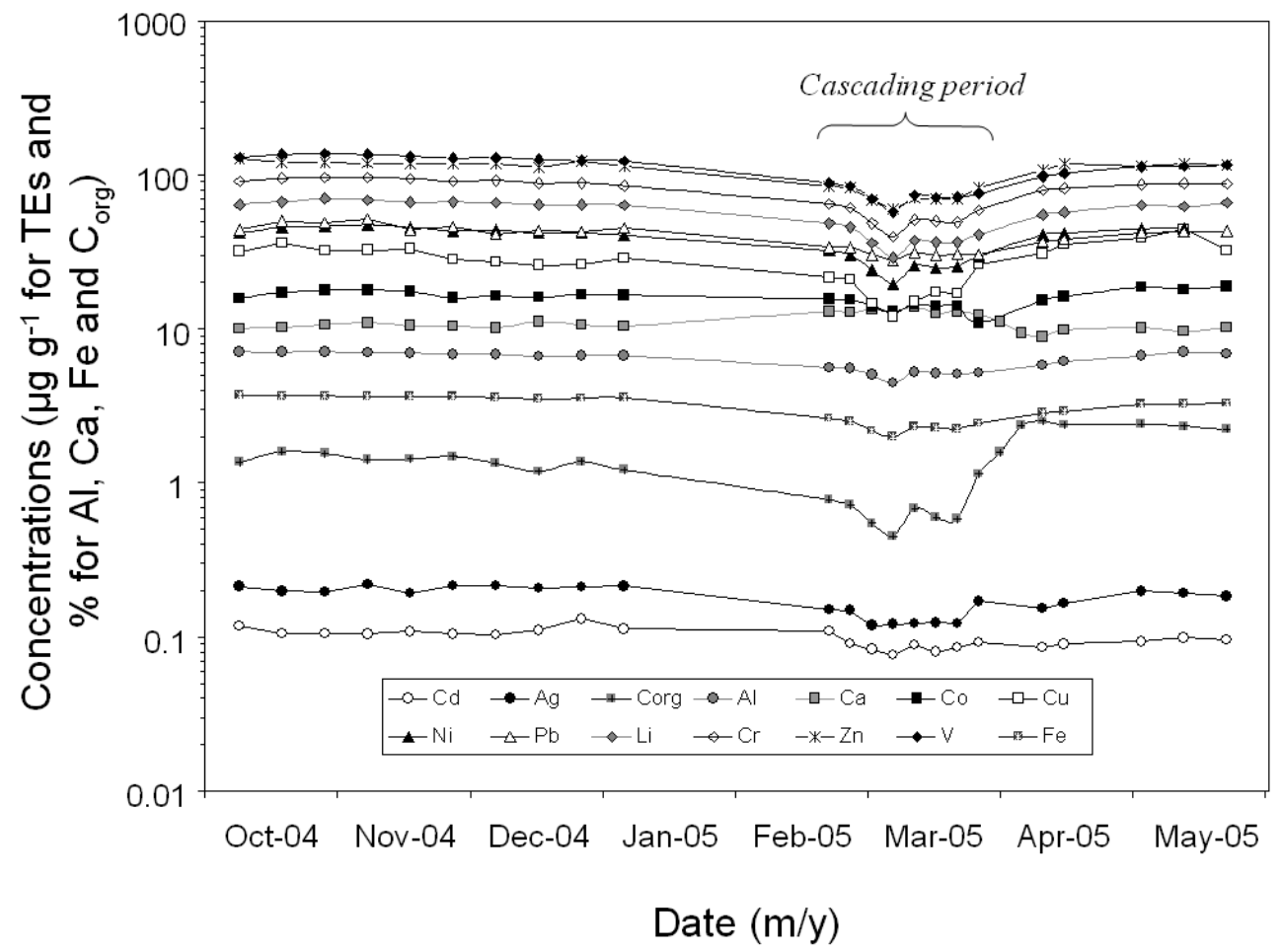

Fig. 2 

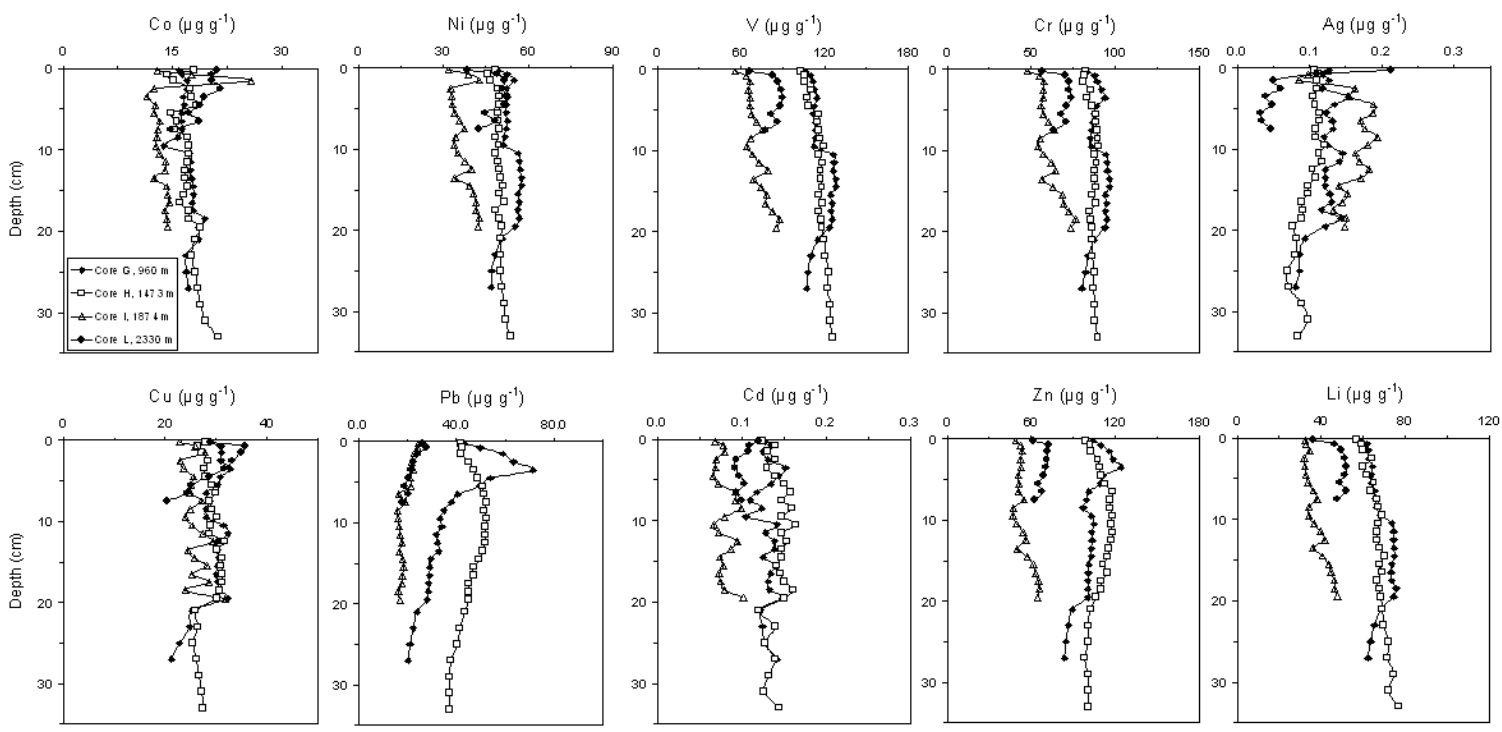

Fig. 3 

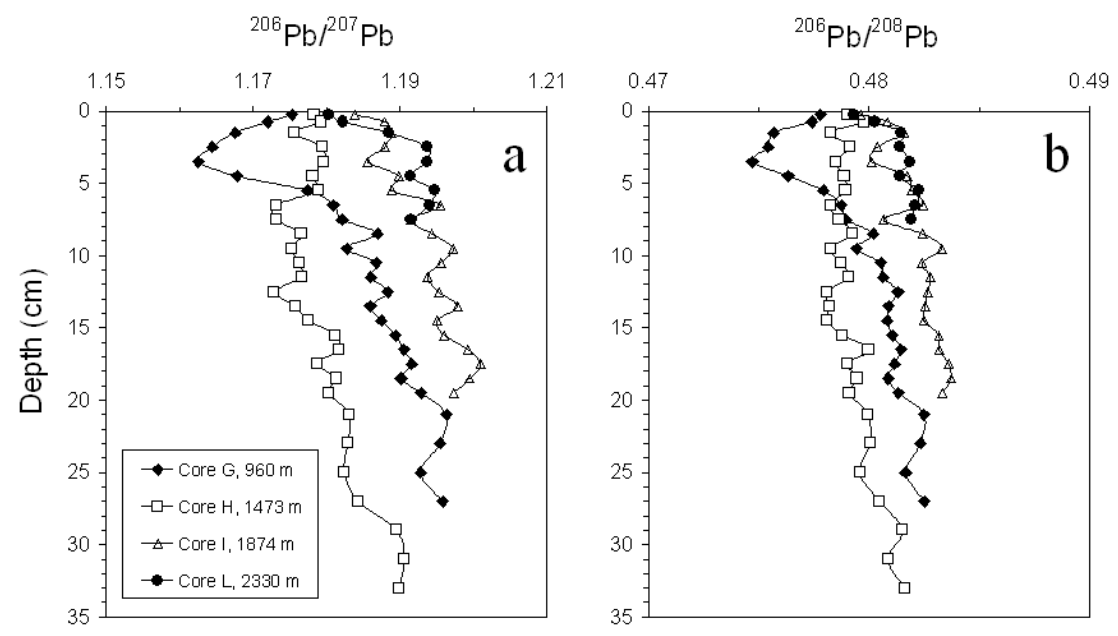

Fig. 4 

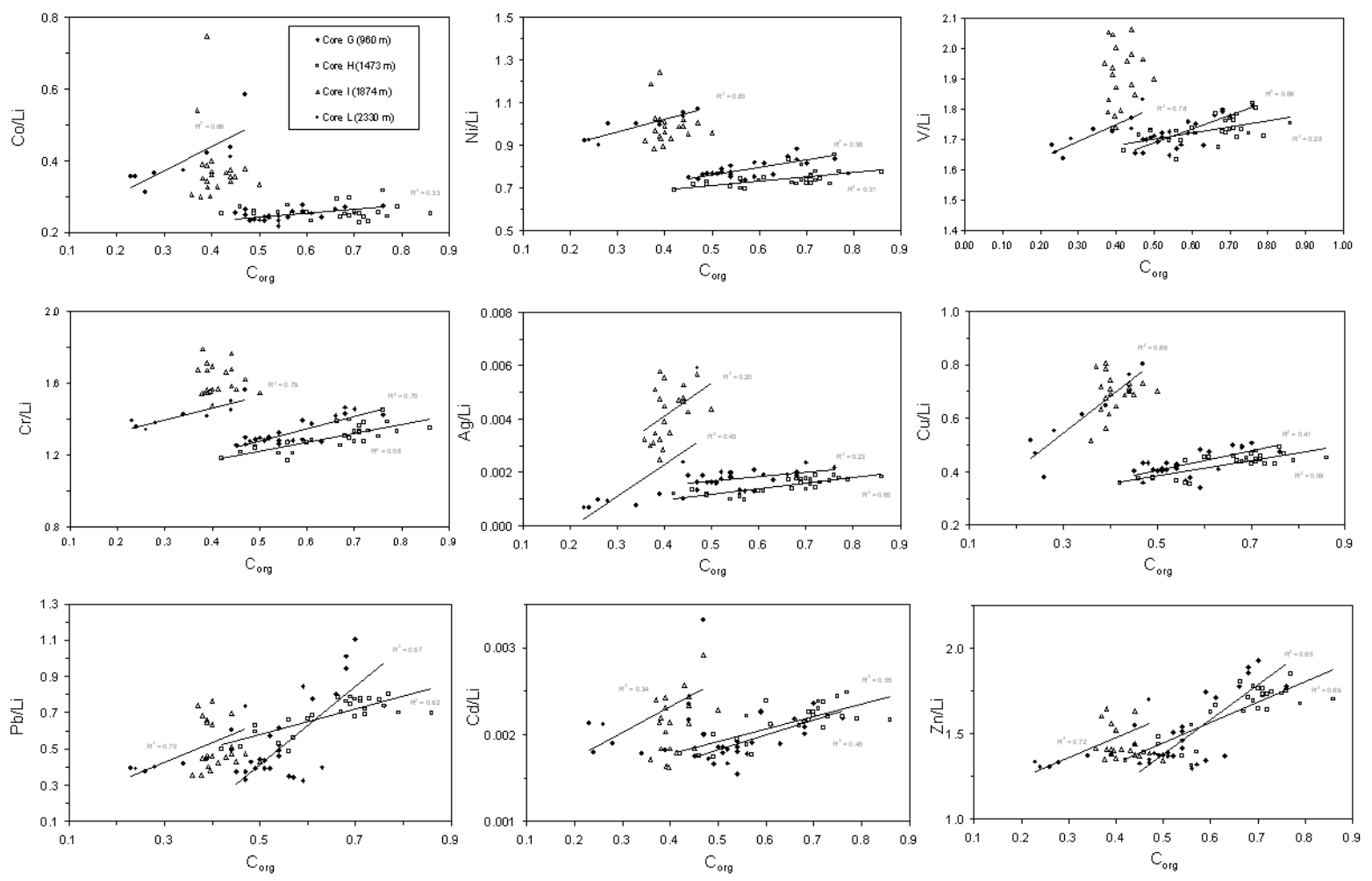

Fig. 5 


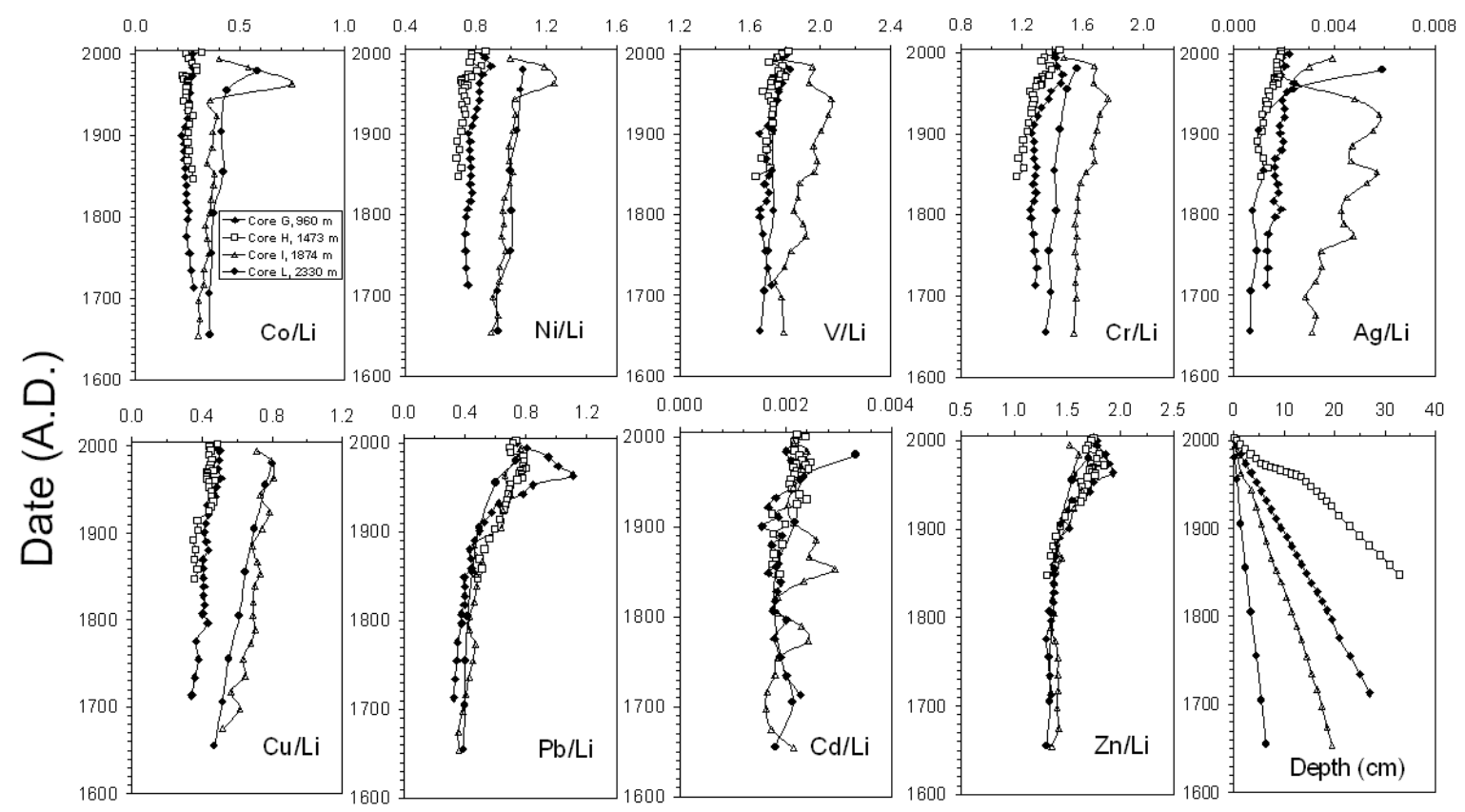

Fig. 6 


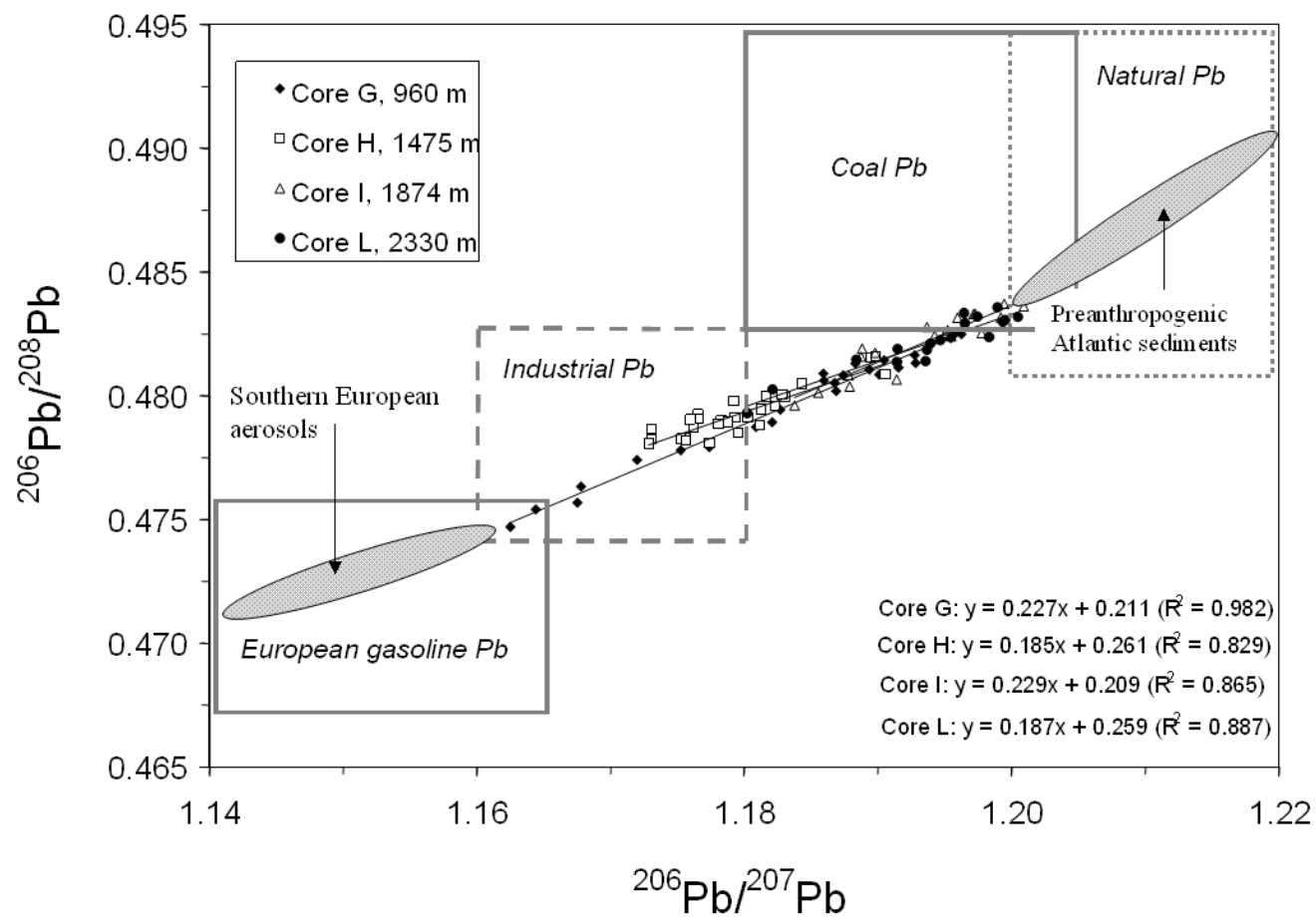

Fig. 7 


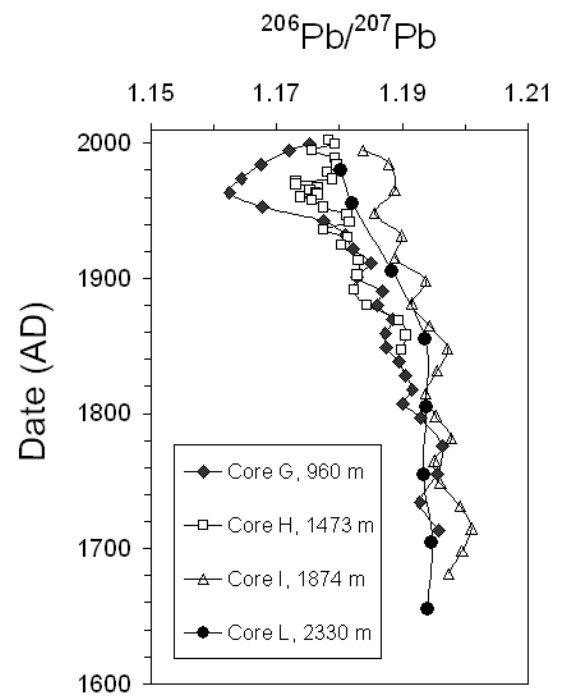

Fig. 8 